

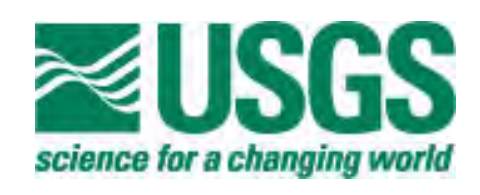

In cooperation with the U.S. Department of Energy, National Nuclear Security Administration Nevada Site Office

\section{Characteristics of Fault Zones in Volcanic Rocks Near Yucca Flat, Nevada Test Site, Nevada}

By Donald Sweetkind and Ronald M. Drake II

Open-File Report 2007-1293 


\section{U.S. Department of the Interior DIRK KEMPTHORNE, Secretary}

\section{U.S. Geological Survey \\ Mark D. Myers, Director}

U.S. Geological Survey, Reston, Virginia 2007

Prepared in cooperation with the U.S. Department of Energy, National Nuclear Security Administration Nevada Site Office under Interagency Agreement, DEAl52-07NA28100

For product and ordering information:

World Wide Web: http://www.usgs.gov/pubprod

Telephone: 1-888-ASK-USGS

For more information on the USGS - the Federal source for science about the Earth, its natural and living resources, natural hazards, and the environment:

World Wide Web: http://www.usgs.gov

Telephone: 1-888-ASK-USGS

Suggested citation:

Sweetkind, D.S., and Drake, R.M., II, 2007, Characteristics of fault zones in volcanic rocks near Yucca Flat, Nevada Test Site, Nevada: U.S. Geological Survey Open-File Report 2007-1293, 52 p.

Any use of trade, product, or firm names is for descriptive purposes only and does not imply endorsement by the U.S. Government. This report has not been reviewed for stratigraphic nomenclature.

Although this report is in the public domain, permission must be secured from the individual copyright owners to reproduce any copyrighted material contained within this report. 


\section{Contents}

Abstract

Introduction and Rationale of the Study ...............................................................................................

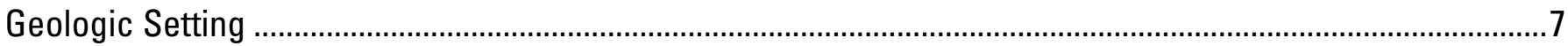

Methods of Geologic Mapping and Fault Zone Data Collection ....................................................................

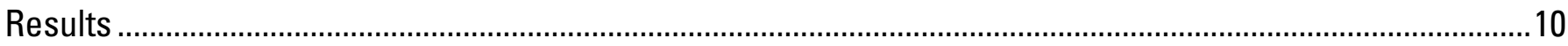

Discussion

References

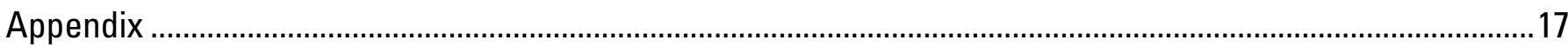

\section{Figures}

Figure 1. Location of outcrop stations and drill holes in Yucca Flat and surrounding areas

Figure 2. Relation between fault displacement and maximum width of fault damage zones in welded, nonwelded, and zeolitized tuff

Figure A1. Location of outcrop stations and drill holes in Yucca Flat and surrounding areas .....................18

Figure A2. View, looking southeast, of faults in Calico Hills Formation, south of Rainier Mesa .................20

Figure A3. Detail of the fault zone showing the slip surface, fault core zones $(A)$, and the two faultrelated damage zones (B and $C$ )

Figure A4. View, looking south, of fault in Redrock Valley that offsets red Grouse Canyon Tuff and underlying tan and grey beds of the Tunnel Formation

Figure A5. View, looking south, of fault-related deformation in the hanging wall ......................................23

Figure A6. View looking northeast of minor faults within nonwelded tuff of the Tunnel Formation.............25

Figure A7. Detail of fault zone in nonwelded pumiceous tuff at north end of Shoshone Mountain..............27

Figure A8. View of stepover between two normal fault strands (white lines), showing decimeter-scale fracturing between the two faults ........................................................................................27

Figure A9. Detail of clast-supported breccia consisting of 1-centimeter angular fragments of hanging-

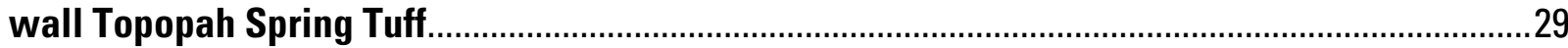

Figure A10. View, looking north, of fault in zeolitized Tunnel Formation ...................................................31

Figure A11. Detail of fault in zeolitized Tunnel Formation showing the fault and three fault-related damage zones in the hanging wall (labeled A, B, and C).

Figure A12. View, looking south, of faults in massive, pumiceous nonwelded tuff of the Tunnel Formation

Figure A13. Detail of fault in Tunnel Formation ....................................................................................3

Figure A14. View of fault zone on eastern flank of Rainier Mesa

Figure A15. View of fault in Tunnel Formation on east flank of Rainier Mesa ...........................................37

Figure A16. View, looking northwest of faults in Tunnel Formation on east flank of Rainier Mesa ............39

Figure A17. Detail of fracturing present in hanging-wall rocks at station 06NTS5 ......................................39

Figure A18. View of small fault in Tunnel Formation ..........................................................................

Figure A19. Detail of fault plane showing locally polished surface ……………………............................ 41

Figure A20. View of small strike-slip fault in Tunnel Formation ................................................................4

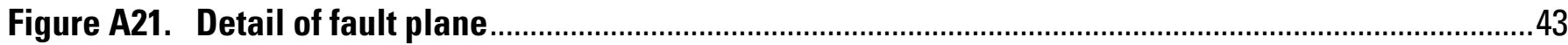

Figure A22. View from ridgeline looking down and to the north on station 06NTS08 …............................46 
Figure A23. Detail of fault zone, looking northwest, parallel to the strike of the fault .46 Figure A24. Numerous small strike-slip faults in poorly welded Bullfrog Tuff south of Rainier Mesa .......48 Figure A25. Detail of slip planes showing well-developed slickenlines

\section{Tables}

Table 1. Location of geologic field stations and geophysical study locations.

Table 2. Summary of fault zone characteristics.

\section{Conversion Factors}

\begin{tabular}{lll}
\hline \multicolumn{1}{c}{ Multiply } & \multicolumn{1}{c}{ By } & \multicolumn{1}{c}{ To obtain } \\
\hline inch & 2.54 & centimeter $(\mathrm{cm})$ \\
inch & 25.4 & millimeter $(\mathrm{mm})$ \\
foot (ft) & 0.3048 & meter (m) \\
mile (mi) & 1.609 & kilometer $(\mathrm{km})$ \\
centimeter $(\mathrm{cm})$ & 0.3937 & inch (in.) \\
millimeter $(\mathrm{mm})$ & 0.03937 & inch (in.) \\
meter $(\mathrm{m})$ & 3.281 & foot (ft) \\
kilometer $(\mathrm{km})$ & 0.6214 & mile (mi) \\
\hline
\end{tabular}

Vertical coordinate information is referenced to the North American Vertical Datum of 1988 (NAVD88).

Horizontal coordinate information is referenced to the North American Datum of 1983 (NAD 83).

Elevation, as used in this report, refers to distance above the vertical datum. 


\title{
Characteristics of Fault Zones in Volcanic Rocks near Yucca Flat, Nevada Test Site, Nevada
}

\author{
By Donald S. Sweetkind and Ronald M. Drake II
}

\begin{abstract}
During 2005 and 2006, the USGS conducted geological studies of fault zones at surface outcrops at the Nevada Test Site. The objectives of these studies were to characterize fault geometry, identify the presence of fault splays, and understand the width and internal architecture of fault zones. Geologic investigations were conducted at surface exposures in upland areas adjacent to Yucca Flat, a basin in the northeastern part of the Nevada Test Site; these data serve as control points for the interpretation of the subsurface data collected at Yucca Flat by other USGS scientists. Fault zones in volcanic rocks near Yucca Flat differ in character and width as a result of differences in the degree of welding and alteration of the protolith, and amount of fault offset. Fault-related damage zones tend to scale with fault offset; damage zones associated with large-offset faults $(>100 \mathrm{~m})$ are many tens of meters wide, whereas damage zones associated with smaller-offset faults are generally a only a meter or two wide. Zeoliticallyaltered tuff develops moderate-sized damage zones whereas vitric nonwelded, bedded and airfall tuff have very minor damage zones, often consisting of the fault zone itself as a deformation band, with minor fault effect to the surrounding rock mass. These differences in fault geometry and fault zone architecture in surface analog sites can serve as a guide toward interpretation of high-resolution subsurface geophysical results from Yucca Flat.
\end{abstract}

\section{Introduction and Rationale of the Study}

Between the years 1951 and 1992, 659 underground nuclear tests took place in Yucca Flat (U.S. Department of Energy, 2000), a topographic and structural basin in the northeastern part of the Nevada Test Site (NTS) in Nye County, Nevada (fig. 1). Significant geologic aspects of the Yucca Flat basin are Neogene normal faults that disrupt the Cenozoic and pre-Cenozoic rocks within the basin (Slate and others, 2000; Phelps and McKee, 1999). The location and characteristics of these faults may influence ground-water flow through fault offset that results in the juxtaposition of stratigraphic units with contrasting hydrologic properties, or because of special physical characteristics of the fault zones, such as brecciation and fracturing, that may cause specific parts of the zone to act either as conduits or as barriers to fluid flow. In addition, knowledge of fault zone architecture and physical properties is a fundamental component of the containment of underground nuclear tests (Carothers, 1995), should such testing ever resume at the NTS. Previous surface geologic mapping (Slate and others, 2000), geophysical studies (Ferguson and others, 1988; Phelps and others, 1999; Phelps and McKee, 1999), and data from hundreds of drill holes in Yucca Flat (Covington and Berger, 1997) have defined the location and magnitude of offset of faults in the basin. However, relatively less attention has been paid to fault geometry and the internal architecture (Caine and others, 1996; Kim and others, 2004) of fault zones. 

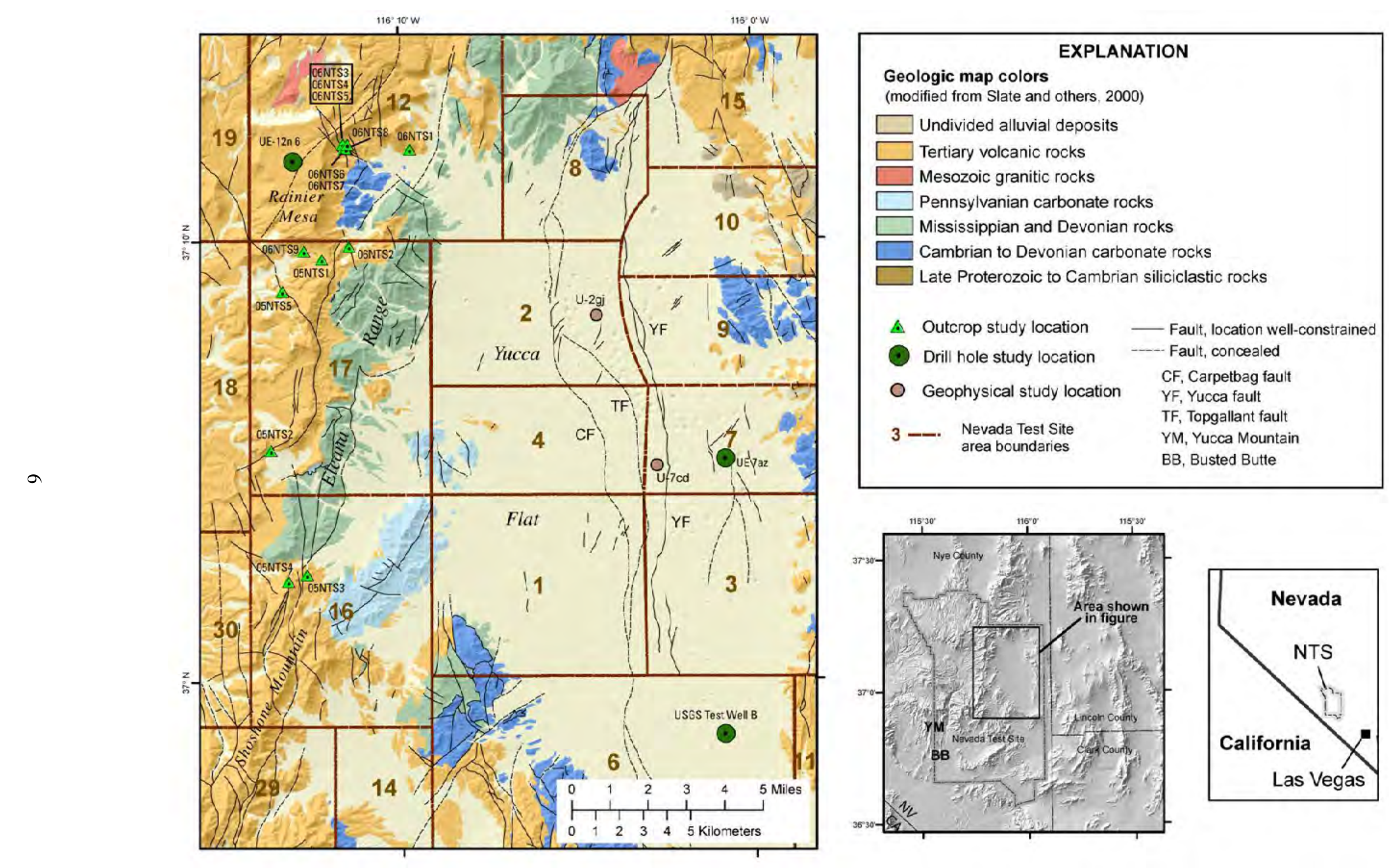

Figure 1. Location of outcrop, drill-hole, and geophysical study locations in Yucca Flat and surrounding areas. 
During 2005 and 2006, the USGS conducted geological and geophysical studies of fault zones at the NTS to investigate faults at Yucca Flat in greater detail. The objectives of these studies were to characterize fault geometry, identify the presence of fault splays, and understand the width and internal architecture of fault zones. A variety of surface-based geophysical data was collected in the vicinity of two drill holes in Yucca Flat that are near fault zones (T.H. Asch and others, U.S. Geological Survey, 2007, written commun.). Geologic investigations were conducted at surface exposures in upland areas adjacent to Yucca Flat; these data serve as control points for the interpretation of the subsurface data. The two types of data-collection activities go hand in hand in terms of understanding the character of fault zones beneath Yucca Flat; geophysical data are collected on the faults in the subsurface, and the outcrop data serve as potential analogs that provide the geologic information necessary to interpret the geophysical results and reduce uncertainty in our subsurface interpretation.

The goal of the present investigation is to develop an understanding of the geometry and physical properties of fault zones in outcrop near Yucca Flat so that these data might be used in the interpretation of geophysical data for subsurface fault zones. This report presents descriptive field data that document the geometry and architecture of fault zones in welded, nonwelded, and zeolitized volcanic rocks based on surface outcrop observation at 14 locations and data from three drill cores (fig. 1). In addition, these descriptive data provide important information on deformation in volcanic rocks from well-exposed volcanic sections at the NTS that are not accessible to the general public.

\section{Geologic Setting}

The rocks within the Yucca Flat basin consist of a thick alluvial section underlain by Miocene volcanic rocks and rare, thin, prevolcanic sedimentary rocks, all of which lie unconformably on variably deformed pre-Cenozoic rocks. The pre-Cenozoic rocks show evidence of contractional deformation related to generally east- and southeast-directing thrust faults during Mesozoic time (Caskey and Schweickert, 1992; Cole and Cashman, 1999). During late Cenozoic time, these rocks and the Cenozoic-age basin fill were affected by east-west extension that resulted in the formation of predominantly north-striking normal faults (Hinrichs, 1968; Carr, 1984; Minor, 1995). The Cenozoic volcanic units within the basin have been tilted to the west and offset hundreds of meters by the major normal faults including the Carpetbag, Topgallant, and Yucca faults (fig. 1); numerous faults with lesser offset exist as well. Gravity models of the Yucca Flat basin define a Tertiary-Quaternary basin as much as 2,500 m deep to the east of the Carpetbag and Yucca faults, a midbasin high to the west of the Carpetbag fault, and a shallower basin to the west of the midbasin high (Ferguson and others, 1988; Phelps and others, 1999). Offset of Holocene alluvial deposits along the Yucca fault in central Yucca Flat indicates deformation in the area has continued into the Holocene (Swadley and Hoover, 1990).

In 2005 and 2006 the U.S. Geological Survey conducted surface-based geophysical investigations in the vicinity of two drill holes in Yucca Flat: U-7cd and U-2gj (table 1, fig. 1). These two localities were chosen for their ease of access for the purposes of geophysical data collection, proximity to known or suspected faults, proximity to regional magnetotelluric (MT) survey sites (Asch and others, 2006), and potential utility of the results from these sites to the U.S. Department of Energy. Drill hole U-7cd is in the footwall of the Yucca fault (fig. 1), an east-dipping, east-side-down normal fault with 200 to $400 \mathrm{~m}$ of offset and a prominent surface scarp. Although the fault is generally north-striking, it is distinctly sinuous in detail, probably as a result of en-echelon linked segments. Surface-based geophysical traverses (Asch and others, 2007, written commun.) were designed to cross the trace of the fault, evaluate the extent of footwall damage (that is, brecciation and fault-related fracturing), and investigate possible 
hanging-wall splay faults. Farther to the north, drill hole U-2gj is roughly equidistant $(2 \mathrm{~km})$ from the Yucca fault and the Carpetbag/Topgallant fault system (fig. 1). Surficial geologic mapping (Slate and others, 2000) and analysis of surface effects (Grasso, 2001) suggest the presence of small-offset faults. Geophysical surveys at this location were designed to investigate small-offset faults distant from the major mapped normal faults in the basin (T.H. Asch and others, U.S. Geological Survey, 2007, written commun.).

Yucca Flat is bordered on its west and northwest sides by uplands of variably deformed pre-Cenozoic rocks (Cole and Cashman, 1999) overlain by Miocene volcanic rocks. The volcanic rocks were erupted from source areas in the southwestern Nevada volcanic field (SWNVF) (Byers and others, 1976; Sawyer and others, 1994) that lie to the west of Yucca Flat (fig. 1). The SWNVF deposits consist of regionally-extensive and large-volume ash-flow tuffs, numerous but less extensive and smaller-volume ash-flow tuffs, silicic lava flows and lava domes, fallout tephra deposits, and minor redeposited tuffaceous and epiclastic rocks (Byers and others, 1976; Carr and others, 1986; Byers and others, 1989; Ferguson and others, 1994; Sawyer and others, 1994).

Geological studies of fault zones in the Miocene volcanic rocks were conducted in the uplands to the west of Yucca Flat, generally from the flanks of Rainier Mesa southward to near Shoshone Mountain (fig. 1). The Miocene volcanic rocks were targeted for study based on the availability of locally well-exposed faults and the expectation that much of the data from surfacebased geophysical traverses in Yucca Flat would come from the Miocene volcanic section. The Miocene volcanic section at Rainier Mesa generally consists of a thick caprock of welded Rainier Mesa Tuff overlying much less resistant bedded and nonwelded tuffs. The stratigraphic sequence beneath the capping Rainier Mesa Tuff, from the top downwards, consists of (1) a 60to 185-m-thick sequence of nonwelded and bedded tuffs and tuffaceous sedimentary rocks generally equivalent to, and interfingered with, the Paintbrush Group and Calico Hills Formation (locally mapped as Calico Hills Formation by Slate and others, 2000); (2) 25- to 145-m-thick, welded and bedded parts of the Grouse Canyon Tuff; (3) a 180- to 320-m-thick section of bedded and nonwelded tuff, pumiceous airfall and subordinate reworked tuff of the Tunnel Formation (Tn of Slate and others, 2000), a sequence that includes several informal mappable units (Hansen and others, 1963; Carroll, 1989). Most of the lower volcanic section has been variably altered to zeolite minerals as a result of postdepositional reactions with ground water. Outcrop stations south of Rainier Mesa were in the same part of the stratigraphic section previously described.

The volcanic uplands to the west of Yucca Flat are generally little affected by Tertiary extension as shown by minimal stratal tilt and small-offset faults (Minor, 1995; Slate and others, 2000). Detailed surface geologic mapping (Gibbons and others, 1963; Hansen and others, 1963) and subsurface data from mining and drilling reveal numerous small-displacement faults, but no large-offset faults such as the Yucca Fault. Normal faults on Rainier Mesa mostly strike northnorthwest and dip steeply (70 degrees to vertical). Most field stations at Rainier Mesa were at faults with displacements of less than $10 \mathrm{~m}$ (Gibbons and others, 1963; Hansen and others, 1963). The largest mapped stratigraphic offsets are 30 to $50 \mathrm{~m}$ (Gibbons and others, 1963). Faults to the south of Rainier Mesa and at Shoshone Mountain are more numerous and of larger displacement than faults at Rainier Mesa. One field station to the south of Rainier Mesa (Station 05NTS5, Appendix) was along a fault with about $100 \mathrm{~m}$ of mapped offset; another station at the north end of Shoshone Mountain (Station 05NTS4, Appendix) was along a fault with about $55 \mathrm{~m}$ of mapped offset. 


\section{Methods of Geologic Mapping and Fault Zone Data Collection}

Geologic mapping and fault zone data collection were conducted at surface locations west and northwest of Yucca Flat (fig. 1) where the volcanic section that exists at depth beneath Yucca Flat is exposed at the surface. Descriptive field data were collected at 14 surface outcrop locations and from three drill cores (table 1); these sites are collectively referred to as geologic field stations in this report. Field investigations concentrated on describing fault geometry (number of splays, fault curvature, and linkage) and fault zone architecture (width of fault core and damage zones, asymmetry of damage in hanging wall and footwall) in welded, nonwelded, and zeolitized tuff (Appendix).

Geologic mapping and fault zone data collection were conducted at well-exposed fault zones from 14 surface outcrops (Appendix). In all cases, existing 1:24,000-scale geologic maps (for example, Gibbons and others, 1963; Orkild, 1963) and digital orthophotographs were used as a guide, but rigorous field checking was required to verify fault offsets and to identify suitably exposed portions of fault zones for study. At each geologic field station, the following properties of the mapped fault were measured: location, fault orientation, sense of slip and amount of offset, mapped length of fault trace, and lithologic unit in hanging wall and footwall of fault (Appendix). At each exposure, fault-related rocks were subdivided into three classes, following the definitions of Caine and others (1996) and Kim and others (2004): (1) a fault core that is adjacent to the slip plane and composed of clay-rich gouge, highly comminuted rock, or matrixsupported breccia; (2) a damage zone of clast-supported breccia and fractured rock surrounding the fault core; and (3) a protolith of relatively undamaged rock at some distance from the fault. Fault cores were described by documenting, to the extent that surface exposures allowed, the core zone width, clast type, size, shape, sorting and angularity, degree of clast rotation, relative degree of clast or matrix support, matrix material, degree of cementation, alteration or mineralization, presence of clay gouge, the nature of contacts with damage zone, and the presence of preferred fabric. Damage zones were described by documenting, to the extent that surface exposures allowed, width in hanging wall and footwall of fault, nature of contacts with fault core and protolith, changes in fracture orientation and intensity (or presence of new fracture sets), presence of fault splays or offset in hanging wall and footwall of fault, presence of breccia, noting clast size, shape and angularity, and degree of clast rotation, cementation, alteration or mineralization. The protolith was described by noting the degree of welding and the nature of the fracture fabric of the protolith where it appeared to represent background, unbroken rock. Where possible, samples were collected for microscopic petrographic analysis in order to evaluate degree of comminution and clast abrasion.

Measurements and descriptions on faults in the drill cores followed the procedures outlined above as much as possible. The specific core intervals were chosen for description based on the degree of core recovery, allowing for examination of fault core and damage zones and on availability of supporting documentation and reports (Jerry Magner, U.S. Geological Survey, oral commun., 2006). 
Table 1. Location of geologic field stations and geophysical study locations.

\begin{tabular}{|c|c|c|c|c|c|}
\hline Name & Latitude NAD 83 & Longitude NAD 83 & $\begin{array}{l}\text { NTS } \\
\text { area }\end{array}$ & Type & $\begin{array}{c}\text { Related figures in } \\
\text { Appendix }\end{array}$ \\
\hline 05NTS1 & $37^{\circ} 9^{\prime} 35.1^{\prime \prime}$ & $-116^{\circ} 12^{\prime} 17.5^{\prime \prime}$ & 17 & Outcrop & $\mathrm{A} 2, \mathrm{~A} 3$ \\
\hline 05NTS2 & $37^{\circ} \quad 5^{\prime} 14.6 ”$ & $-116^{\circ} 13^{\prime} 46.2^{\prime \prime}$ & 17 & Outcrop & $\mathrm{A} 4, \mathrm{~A} 5$ \\
\hline 05NTS3 & $37^{\circ} \quad 2^{\prime} 25.3^{\prime \prime}$ & $-116^{\circ} 12^{\prime} 46.5^{\prime \prime}$ & 16 & Outcrop & A6 \\
\hline 05NTS4 & $37^{\circ} \quad 2^{\prime} 15.9^{\prime \prime}$ & $-116^{\circ} 13^{\prime} 18.2^{\prime \prime}$ & 16 & Outcrop & $\mathrm{A} 7, \mathrm{~A} 8$ \\
\hline 05NTS5 & $37^{\circ} \quad 8^{\prime} 51.5$ & $-116^{\circ} 13^{\prime} 24.3^{\prime \prime}$ & 17 & Outcrop & A9 \\
\hline 06NTS1 & $37^{\circ} 12^{\prime} \quad 4.0^{\prime \prime}$ & $-116^{\circ} 9^{\prime} 46.1^{\prime \prime}$ & 12 & Outcrop & A10, A11 \\
\hline 06NTS2 & $37^{\circ} \quad 9^{\prime} 52.2^{\prime \prime}$ & $-116^{\circ} 11^{\prime} 30.7^{\prime \prime}$ & 17 & Outcrop & $\mathrm{A} 12, \mathrm{~A} 13$ \\
\hline 06NTS3 & $37^{\circ} 12^{\prime} 11.6^{\prime \prime}$ & $-116^{\circ} 11^{\prime} 40.5^{\prime \prime}$ & 12 & Outcrop & A 14 \\
\hline 06NTS4 & $37^{\circ} 12^{\prime} \quad 6.3^{\prime \prime}$ & $-116^{\circ} 11^{\prime} 36.0^{\prime \prime}$ & 12 & Outcrop & A15 \\
\hline 06NTS5 & $37^{\circ} 12^{\prime} \quad 5.3^{\prime \prime}$ & $-116^{\circ} 11^{\prime} 36.5^{\prime \prime}$ & 12 & Outcrop & A16, A17 \\
\hline 06NTS6 & $37^{\circ} 12^{\prime} \quad 5.9^{\prime \prime}$ & $-116^{\circ} 11^{\prime} 34.4^{\prime \prime}$ & 12 & Outcrop & A18, A19 \\
\hline 06NTS7 & $37^{\circ} 12^{\prime} \quad 5.8^{\prime \prime}$ & $-116^{\circ} 11^{\prime} 34.3^{\prime \prime}$ & 12 & Outcrop & $\mathrm{A} 20, \mathrm{~A} 21$ \\
\hline 06NTS8 & $37^{\circ} 12^{\prime} 11.7^{\prime \prime}$ & $-116^{\circ} 11^{\prime} 32.12^{\prime \prime}$ & 12 & Outcrop & $\mathrm{A} 22, \mathrm{~A} 23$ \\
\hline 06NTS9 & $37^{\circ}$ 9' 46.6" & $-116^{\circ} 12^{\prime} 47.6^{\prime \prime}$ & 17 & Outcrop & $\mathrm{A} 24, \mathrm{~A} 25$ \\
\hline UE-12n 6 & $37^{\circ} 11^{\prime} 48.9^{\prime \prime}$ & $-116^{\circ} 13^{\prime} \quad 4.0^{\prime \prime}$ & 12 & Drill hole & none \\
\hline UE-7az & $37^{\circ} 5^{\prime} \quad 0.0^{\prime \prime}$ & $-116^{\circ} 0^{\prime} 51.4^{\prime \prime}$ & 7 & Drill hole & none \\
\hline $\begin{array}{l}\text { USGS Test } \\
\text { Well B }\end{array}$ & $36^{\circ} 58^{\prime} 44.7^{\prime \prime}$ & $-116^{\circ} \quad 0^{\prime} 55.7^{\prime \prime}$ & 6 & Drill hole & none \\
\hline U-7ed & $37^{\circ} 4^{\prime} 51^{\prime \prime}$ & $-116^{\circ} 2^{\prime} 44.4^{\prime \prime}$ & 7 & $\begin{array}{l}\text { Geophysical } \\
\text { study location }\end{array}$ & none \\
\hline $\mathrm{U}-2 \mathrm{gj}$ & $37^{\circ} \quad 7$ '38.9” & $-116^{\circ} 3^{\prime} 34.8^{\prime \prime}$ & 2 & $\begin{array}{l}\text { Geophysical } \\
\text { study location }\end{array}$ & none \\
\hline
\end{tabular}

\section{Results}

Results from field data collection are tabulated in table 2. Despite the small number of field stations, relative degree of development of fault-related damage zones appears to be influenced by fault displacement, volcanic rock type, and presence of zeolitic alteration (fig. 2). The fault with the widest damage zone, geologic field station 05NTS2, is in densely welded tuff (fig. 2A). The damage zone associated with this fault consists of minor subsidiary fault splays, and a very wide, complex zone of highly fractured and brecciated rock (fig. A4, Appendix). Similar broad damage zones in densely welded tuff have been observed at Yucca Mountain, on the west edge of the NTS (fig. 1) where, for example, a damage zone 25 to $30 \mathrm{~m}$ wide is developed in the Tiva Canyon Tuff along a fault with $27 \mathrm{~m}$ of down-to-the-west offset (Sweetkind and others, 1997). The fault at geologic field station 05NTS5 (fig. A9, Appendix) has the greatest amount of displacement of any fault studied (fig. 2). The hanging-wall rocks are densely welded Topopah Spring Tuff whereas footwall rocks are nonwelded Bullfrog Tuff. The presence of nonwelded tuff may serve to reduce the anticipated large width of the fault damage 
zone here in that the lower strength nonwelded tuff may yield preferentially and reduce the amount of fault-related damage in the welded rocks. A similar situation is observed in the Exploratory Tunnel Facilities Tunnel beneath Yucca Mountain (fig. 1) where nonwelded Rainier Mesa Tuff is juxtaposed against welded Tiva Canyon Tuff along the Bow Ridge fault, a downto-the west fault with $100 \mathrm{~m}$ of displacement. In this case, the damage zone developed within the welded tuff is about $3 \mathrm{~m}$ wide, and damage in the nonwelded rocks is relatively minimal (Beason and others, 1996).
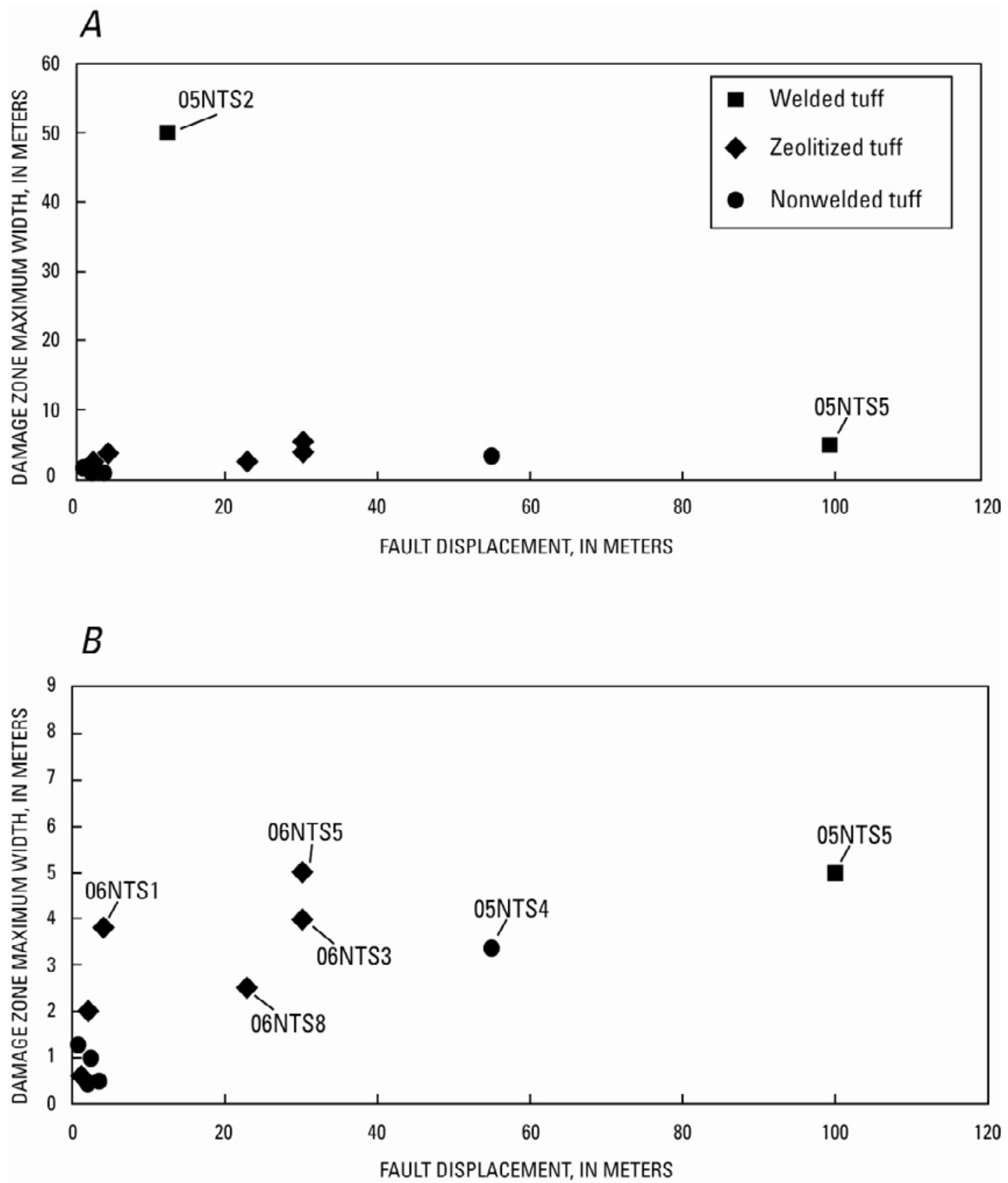

Figure 2. Relation between fault displacement and maximum width of fault damage zones in welded, nonwelded, and zeolitized tuff. Data are presented for all faults (A) and for faults with damage zones less than 10 meters wide (B). 
Table 2. Summary of fault zone characteristics.

[cm, centimeter; m, meter; mm, millimeter; <, less than; >, greater than; ---, no data]

\begin{tabular}{|c|c|c|c|c|c|c|c|c|c|c|c|}
\hline \multirow[t]{2}{*}{$\begin{array}{l}\text { Field } \\
\text { station }\end{array}$} & \multirow[t]{2}{*}{$\begin{array}{l}\text { Displacement, } \\
\text { m }\end{array}$} & \multirow[t]{2}{*}{ Strike } & \multirow[t]{2}{*}{ Dip } & \multirow[t]{2}{*}{$\begin{array}{l}\text { Offset } \\
\text { sense }^{1}\end{array}$} & \multirow[t]{2}{*}{$\begin{array}{l}\text { HW } \\
\text { lithology }\end{array}$} & \multirow[t]{2}{*}{$\begin{array}{c}\text { FW } \\
\text { lithology }\end{array}$} & \multicolumn{2}{|c|}{$\begin{array}{l}\text { Core zone } \\
\text { elements }\end{array}$} & \multicolumn{3}{|c|}{ Damage zone elements } \\
\hline & & & & & & & $\begin{array}{c}\text { Cataclasite } \\
\text { and foliated } \\
\text { gouge }\end{array}$ & $\begin{array}{l}\text { Matrix- } \\
\text { supported } \\
\text { breccia }\end{array}$ & $\begin{array}{l}\text { Clast- } \\
\text { supported } \\
\text { breccia }\end{array}$ & $\begin{array}{l}\mathrm{HW} \text { increased } \\
\text { fracturing }\end{array}$ & $\begin{array}{l}\text { FW increased } \\
\text { fracturing }\end{array}$ \\
\hline 05NTS1 & 0.3 & 146 & 61 & DTW & NWT & NWT & --- & 5 to $7 \mathrm{~cm}$ & --- & $1.3 \mathrm{~m}$ & --- \\
\hline 05NTS2 & 12 & 235 & 65 & DTW & WT & NWT & covered & covered & $5 \mathrm{~m}$ & $50 \mathrm{~m}$ & $25 \mathrm{~m}$ \\
\hline 05NTS3 & 1 to 3 & 0 & 80 & DTE & NWT & NWT & --- & --- & --- & 30 to $60 \mathrm{~cm}$ & 30 to $60 \mathrm{~cm}$ \\
\hline 05NTS4 & 55 & 0 & 80 & DTE & NWT & NWT & 2 to $5 \mathrm{~mm}$ & --- & $30 \mathrm{~cm}$ & $2 \mathrm{~m}$ & $3 \mathrm{~m}$ \\
\hline 05NTS5 & 100 & 315 & 85 & DTW & WT & PWT & --- & --- & $1 \mathrm{~m}$ & $5 \mathrm{~m}$ & $<5 \mathrm{~m}$ \\
\hline 06NTS1 & 3 to 5 & 190 & 57 & DTW & $\mathrm{ZT}$ & $\mathrm{ZT}$ & 1 to $2 \mathrm{~cm}$ & --- & --- & 3.3 to $4.3 \mathrm{~m}$ & $\begin{array}{c}\text { covered } \\
0.5\end{array}$ \\
\hline 06NTS2 & 2 to 5 & 15 & 55 & DTW & NWT & NWT & --- & --- & --- & $0.5 \mathrm{~m}$ & $\mathrm{~m}$ \\
\hline 06NTS3 & 30 & 190 & 80 & DTW & $\mathrm{ZT}$ & $\mathrm{ZT}$ & --- & --- & --- & $<5 \mathrm{~m}$ & $>2 \mathrm{~m}$ \\
\hline 06NTS4 & 2 & 190 & 75 & DTE & $\mathrm{ZT}$ & ZT & --- & --- & --- & 0 & $2 \mathrm{~m}$ \\
\hline 06NTS5 & 30 & 120 & 80 & DTW & $\mathrm{ZT}$ & $\mathrm{ZT}$ & --- & --- & --- & $5 \mathrm{~m}$ & covered \\
\hline 06NTS6 & 1 & 165 & 77 & DTW & $\mathrm{ZT}$ & ZT & --- & --- & --- & 50 to $70 \mathrm{~cm}$ & --- \\
\hline 06NTS7 & --- & 135 & 85 & LL & $\mathrm{ZT}$ & ZT & --- & --- & --- & --- & --- \\
\hline 06NTS8 & 20 to 25 & 155 & 80 & DTW & $\mathrm{ZT}$ & ZT & --- & $10 \mathrm{~cm}$ & $30 \mathrm{~cm}$ & 2 to $3 \mathrm{~m}$ & $1 \mathrm{~m}$ \\
\hline 06NTS9 & --- & 125 & 85 & LL & $\mathrm{ZT}$ & $\mathrm{ZT}$ & $1 \mathrm{~cm}$ & --- & --- & $30 \mathrm{~cm}$ & $30 \mathrm{~cm}$ \\
\hline UE-12n 6 & 2 to 3 & --- & 60 & DTW & NWT & NWT & $1 \mathrm{~mm}$ & --- & --- & $0.3 \mathrm{~m}$ & $1 \mathrm{~m}$ \\
\hline UE-7az & --- & --- & 50 & --- & NWT & NWT & --- & & $3 \mathrm{~m}$ & $7 \mathrm{~m}$ & $8 \mathrm{~m}$ \\
\hline $\begin{array}{l}\text { UE-7az } \\
\text { USGS }\end{array}$ & --- & --- & 70 & --- & NWT & NWT & $4 \mathrm{~mm}$ & --- & --- & --- & 0.3 \\
\hline Test Well & & & & & & & & & & & \\
\hline B & --- & --- & 55 & --- & PWT & PWT & --- & & $2 \mathrm{~m}$ & --- & $3 m$ \\
\hline
\end{tabular}

${ }^{1}$ DTW, down-to-west; DTE, down-to-east; LL, left-lateral offset.

${ }^{2}$ HW; hanging wall; FW, footwall; WT, welded tuff; PWT, partly welded tuff; NWT, nonwelded tuff; ZT, zeolitized tuff. 
With the data point from the single fault in welded tuff removed, the remaining data (fig. $2 B$ ) display a more clear relation between fault displacement, rock type, and development of fault-related damage zones. Distinct differences are seen in the width and nature of fault damage zones when welded, nonwelded, and zeolitized tuffs are compared (table 2). For nonwelded and zeolitized tuff, the width of the damage zone shows a general increase with fault displacement (fig. $2 B$ ). In general, large-offset faults (and long faults) have wider damage zones than small faults. This type of scaling relationship has been previously documented for fault zones in other rocks (Hull, 1988). We observed no particular correlation between width of damage zones with fault orientation or dip (table 2). At any given value of fault displacement, zeolitized tuff tends to display wider damage zones than the nonwelded tuff (fig. 2B). Fault displacement in vitric nonwelded and bedded tuffs tends to be localized along narrow zones (for example, geologic field station 05NTS1, figs. A2 and A3, Appendix) similar in appearance to deformation bands in sandstone (Antonellini and Aydin, 1995). These narrow zones are characterized by cataclasis and grain-size reduction; the faults have little influence on the surrounding rock mass. Similar deformation bands in nonwelded tuff have been observed in nonwelded tuff of the Calico Hills Formation at Busted Butte (Wilson and others, 2003), near Yucca Mountain on the west edge of the NTS (fig. 1). Zeolitized tuff, although originally nonwelded and glassy, has been modified to the extent that it is now more cohesive and brittle and develops moderate-sized damage zones (fig. $2 B$ ). Such damage zones are typically regions of elevated fracture intensity a few meters wide, such as at geologic field station 06NTS1 (figs. A10 and A11, Appendix).

\section{Discussion}

The goal of the present investigation is to develop, through geologic inferences based on geologic mapping, an understanding of the geometry and architecture of fault zones at various scales in volcanic rocks near Yucca Flat. Field observations in these rocks utilized generally accepted zonation of fault-related rocks into (1) a fault core that is adjacent to the slip plane and composed of clay-rich gouge or matrix-supported breccia; (2) a damage zone of brecciated and fractured rock surrounding the fault core; and (3) a protolith of relatively undamaged rock at some distance from the fault (Caine and others, 1996; Kim and others, 2004). Volcanic rocks near Yucca Flat display differences in the nature and width of these zones that are related to degree of welding, alteration, and amount of fault offset. Damage zones tend to scale with fault offset; damage zones associated with large-offset faults $(>100 \mathrm{~m})$ are many tens of meters wide, whereas damage zones associated with smaller offset faults are generally a only a meter or two wide. Zeolitized tuff develops moderate-sized damage zones whereas vitric nonwelded, bedded and airfall tuff have very minor damage zones, often consisting of the fault zone itself as a deformation band, with minor fault effect to the surrounding rock mass.

These differences in fault geometry and fault zone architecture in surface analog sites can serve as a guide toward interpretation of high-resolution subsurface geophysical results (Asch and others, 2007). However, fault zones are known to simplify and become more organized at depth (Wallace and Morris, 1986), so caution must be taken in applying data from surface exposures to deeply buried rocks. Shallow-level exposures feature numerous fault splays, complex deformation zones between splays, and generally dilatant behavior. The proximity to the Earth's surface is a factor in the upward-splaying nature of the faults, largely because confining stresses are nearly zero. In addition, Minor (1995) has documented a variable Neogene paleostress history resulting from rotation in the regional stress field and to caldera-related effects. Such paleostress variations may affect the degree of correlation between the study area's surface exposures and faults in Yucca Flat. 


\section{References}

Antonellini, Marco, and Aydin, Atilla, 1995, Effect of faulting on fluid flow in porous sandstones-geometric properties: American Association of Petroleum Geologists Bulletin, v. 79, p. 642-671.

Asch, T.H., Rodriguez, B.D., Sampson, J.A., Wallin, E.L., and Williams, J.M., 2006, Deep resistivity structure of Yucca Flat, Nevada Test Site, Nevada: U.S. Geological Survey Open-File Report 06-1261, 86 p.

Beason, S.C., Turlington, G.A., Lung, R.C., Eatman, G.L., Ryter, D., and Barr, D.L., 1996, Geology of the North Ramp-Stations 0+60 to 4+00, Exploratory Studies Facility, Yucca Mountain Project, Yucca Mountain, Nevada: Summary report by the U.S. Bureau of Reclamation to the U.S. Department of Energy, 174 p., 15 plates.

Byers, F.M., Jr., Carr, W.J., and Orkild, P.P., 1989, Volcanic centers of southwestern NevadaEvolution of understanding, 1960-1988: Journal of Geophysical Research, v. 94, no. B5, p. 5908-5924.

Byers, F.M., Jr., Carr, W.J., Orkild, P.P., Quinlivan, W.D., and Sargent, K.A., 1976, Volcanic suites and related cauldrons of the Timber Mountain-Oasis Valley caldera complex, southern Nevada: U.S. Geological Survey Professional Paper 919, 70 p.

Caine, J.S., Evans, J.P., and Forster, C.B., 1996, Fault zone architecture and permeability structure: Geology, v. 24, p. 1025-1028.

Carothers, J.E., 1995, Caging the dragon - The containment of underground nuclear explosions: U.S. Department of Energy Report DOE/NV-388, Defense Nuclear Agency Report DNA-TR-95-74, 726 p.

Carr, W.J., 1984, Regional structural setting of Yucca Mountain, southeastern Nevada, and late Cenozoic rates of tectonic activity in part of the southwestern Great Basin, Nevada and California: U.S. Geological Survey Open-File Report 84-854, 98 p.

Carr, W.J., Byers, F.J., Jr., and Orkild, P.P., 1986, Stratigraphic and volcano-tectonic relations of Crater Flat Tuff and some older volcanic units, Nye County, Nevada: U.S. Geological Survey Professional Paper 1323, 28 p.

Carroll, R.D., 1989, Density logging and density of rocks in Rainier Mesa area, Nevada Test Site: U.S. Geological Survey Open-File Report 89-329, 72 p.

Caskey, S.J., and Schweickert, R.A., 1992, Mesozoic deformation in the Nevada Test Site and vicinity-Framework of the Cordilleran Fold and Thrust Belt and Tertiary extension north of Las Vegas Valley: Tectonics, v. 11, p. 1314-1331.

Cole, J.C., and Cashman, P.H., 1999, Structural relationships of pre-Tertiary rocks in the Nevada Test Site region, southern Nevada: U.S. Geological Survey Professional Paper 1607, 39 p.

Covington, H.R., and Berger, M.A., 1997, Catalogue of lithologic and stratigraphic information from drill holes on the Nevada Test Site and environs: U.S. Geological Survey Open-File Report 97-139, 221 p. 
Ferguson, J.F., Cogbill, A.H., and Warren, R.G., 1994, A geophysical-geological transect of the Silent Canyon caldera complex, Pahute Mesa, Nevada: Journal of Geophysical Research, v. 99, p. 4323-4339.

Ferguson, J.F., Felch, R.N., Aiken, C.L.V., Oldow, J.S., and Dockery, Holly, 1988, Models of the Bouguer gravity and geologic structure at Yucca Flat, Nevada: Geophysics, v. 53, p. 231-244.

Gibbons, A.B., Hinrichs, E.N., Hanson, W.R., and Lemke, R.W., 1963, Geology of the Rainier Mesa quadrangle, Nye County, Nevada: U.S. Geological Survey Geologic Quadrangle Map GQ-215, scale 1:24,000.

Grasso, D.N., 2001, GIS surface effects archive of underground nuclear detonations conducted at Yucca Flat and Pahute Mesa, Nevada Test Site, Nevada: U.S. Geological Survey OpenFile Report 2001-0272, 34 p., 1 plate, 1 CD-ROM.

Hansen, W.R., Lemke, R.W., Cattermole, J.M., and Gibbons, A.B., 1963, Stratigraphy and structure of the Rainier and USGS tunnel areas: U.S. Geological Survey Professional Paper 382-A, 49 p., 6 plates.

Hinrichs, E.N., 1968, Geologic structure of the Yucca Flats area, Nevada, in Eckel, E.B., ed., Nevada Test Site: Geological Society of America Memoir 110, p. 239-246.

Hull, Joseph, 1988, Thickness-displacement relationships for deformation zones: Journal of Structural Geology, v. 10, p. 431-435.

Kim, Y.-S., Peacock, D.C.P., and Sanderson, D.J., 2004, Fault damage zones: Journal of Structural Geology, v. 26, p. 503-517.

Minor, S.A., 1995, Superposed local and regional paleostresses fault slip analysis of Neogene extensional faulting near coeval caldera complexes, Yucca Flat, Nevada: Journal of Geophysical Research, v. 100, p. 10507-10528.

Orkild, P.P., 1963, Geologic map of the Tippipah Spring quadrangle, Nye County, Nevada: U.S. Geological Survey Geological Quadrangle Map GQ-213, scale 1:24,000.

Phelps, G.A., Langenheim, V.E., and Jachens, R.C., 1999, Thickness of Cenozoic deposits of Yucca Flat inferred from gravity data, Nevada Test Site, Nevada: U.S. Geological Survey Open-File Report 99-310, 33 p.

Phelps, G.A., and McKee, E.H., 1999, High-angle faults in the basement of Yucca Flat, Nevada Test Site, Nevada, based on analysis of a constrained gravity inversion surface: U.S. Geological Survey Open-File Report 99-383, 6 p.

Sawyer, D.A., Fleck, R.J., Lanphere, M.A., Warren, R.G., Broxton, D.E., and Hudson, M.R., 1994, Episodic caldera volcanism in the Miocene southwestern Nevada volcanic field: revised stratigraphic framework, ${ }^{40} \mathrm{Ar} /{ }^{39} \mathrm{Ar}$ geochronology, and implications for magmatism and extension: Geological Society of America Bulletin, v. 106, p. 13041318.

Slate, J.L., Berry, M.E., Rowley, P.D., Fridrich, C.J., Morgan, K.S., Workman, J.B., Young, O.D., Dixon, G.L., Williams, V.S., McKee, E.H., Ponce, D.A., Hildenbrand, T.G., Swadley, W C, Lundstrom, S.C., Ekren, E.B., Warren, R.G., Cole, J.C., Fleck, R.J., Lanphere, M.A., Sawyer, D.A., Minor, S.A., Grunwald, D.J., Laczniak, R.J., Menges, C.M., Yount, J.C., and Jayko, A.S., 2000, Digital geologic map of the Nevada Test Site 
and vicinity, Nye, Lincoln, and Clark Counties, Nevada, and Inyo County, California: U.S. Geological Survey Open-File Report 99-554A, 53 p., scale 1:120,000; at http://pubs.usgs.gov/of/1999/ofr-99-0554/.

Swadley, W C, and Hoover, D.L., 1990, Geologic map of the surficial deposits of the Yucca Flat area, Nye County, Nevada: U.S. Geological Survey Miscellaneous Investigations Series Map I-2047, scale 1:48,000.

Sweetkind, D.S., Williams-Stroud, S., and Coe, J., 1997, Characterizing the fracture network at Yucca Mountain, Nevada, part 1. Integration of field data for numerical simulations: in, Hoak, T.E., Klawitter, A.L., and Blomquist, P.K., eds., Fractured reservoirsCharacterization and modeling: Rocky Mountain Association of Geologists 1997 Guidebook, p. 185-196.

U.S. Department of Energy, 2000, United States nuclear tests, July 1945 through September 1992: U.S. Department of Energy, Nevada Operations Office, DOE/NV-209 (rev. 15), $162 \mathrm{p}$.

Wallace, R.E., and Morris, H.T., 1986, Characteristics of faults and shear zones in deep mines: Pure and Applied Geophysics ( PAGEOPH ), v. 124, p. 107-125.

Wilson, J.E., Goodwin, L.B., and Lewis, C.J., 2003. Deformation bands in nonwelded ignimbrites-Petrophysical controls on fault-zone deformation and evidence of preferential fluid flow: Geology, v. 31, no. 10, p. 837-840. 


\section{Appendix}

The Appendix consists of the detailed geologic descriptions recorded at outcrop stations and while observing drill core and photographs taken at each outcrop station. Location of outcrop, drill-hole, and geophysical study locations and place names mentioned in this Appendix are given in figure $\mathrm{A} 1$. 

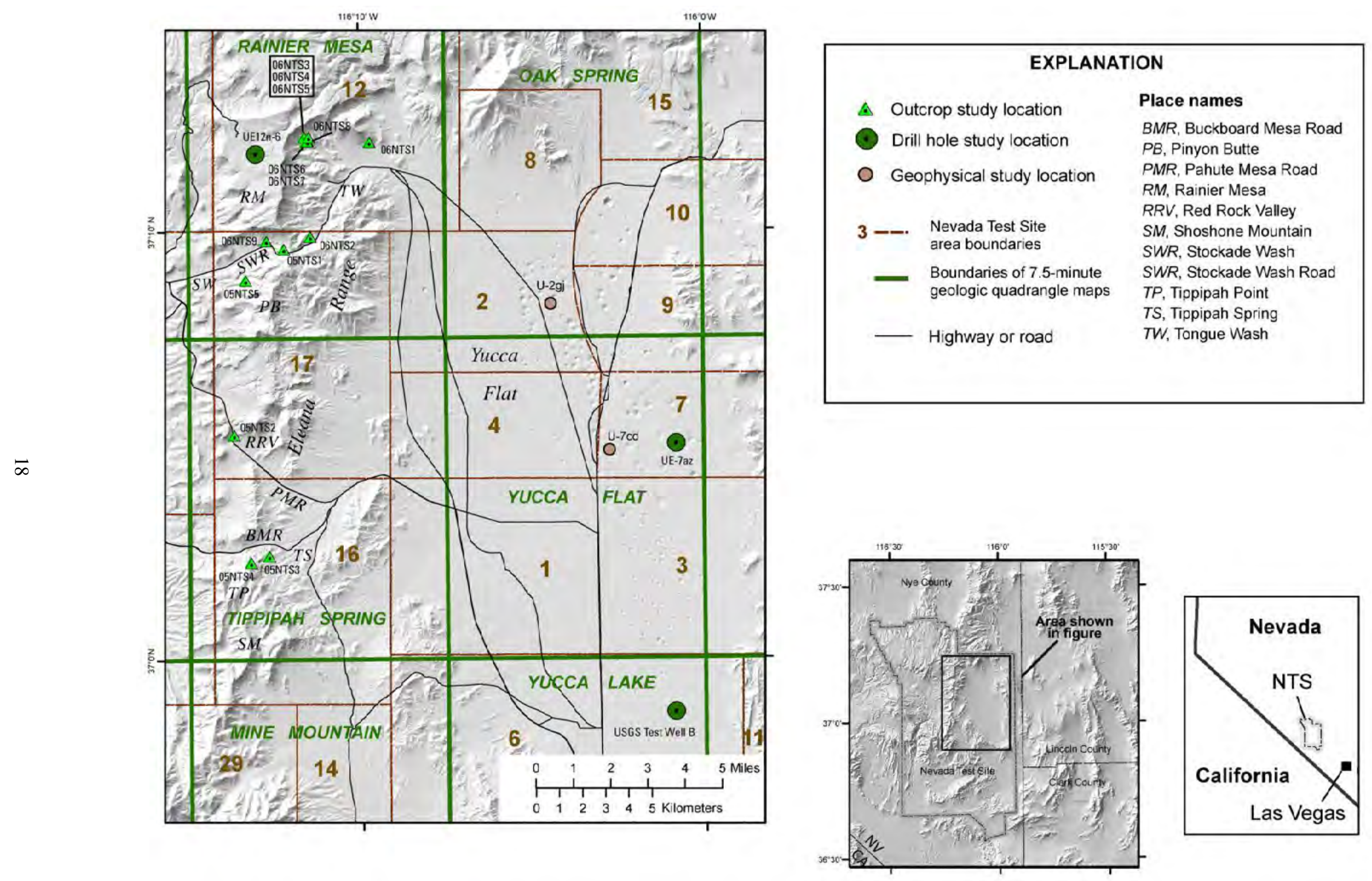

Figure A1. Location of outcrop, drill-hole, and geophysical study locations in Yucca Flat and surrounding areas. 


\section{Field station 05NTS1}

\section{Station description}

Station is located on the Rainier Mesa quadrangle (fig. A1). Station is south of Rainier Mesa, in road cut near the top of the pass between the upper part of Stockade Wash and the upper part of Tongue Wash.

\section{Fault orientation $146^{\circ} / 61^{\circ} \mathrm{W}$.}

\section{Sense of slip and amount of offset}

0.3-m down-to-west offset as measured in outcrop on offset pumiceous beds (fig. A2). A hanging-wall splay fault with minor offset is present about $30 \mathrm{~cm}$ to the west of the main fault.

\section{Length of fault trace in map view}

Fault is not shown on 1:24,000-scale geologic map of the Rainier Mesa quadrangle (Gibbons and others, 1963). Fault trace may not be longer than about $100 \mathrm{~m}$ based on field observations.

\section{Lithologic unit in hanging wall (HW) and footwall (FW)}

Both HW and FW are in pumiceous nonwelded tuff and pumiceous tephra (fig. A1) originally mapped as the Survey Butte Member of the Piapi Canyon Formation (Gibbons and others, 1963); reinterpreted as Calico Hills Formation on the digital map of the NTS (Slate and others, 2000). In this area, the welded tuffs of the Paintbrush Group are absent so that the mapped Calico Hills Formation (Slate and others, 2000) includes all rock units between the top of the underlying Bullfrog Tuff and the Timber Mountain Group rocks that cap Rainier Mesa. The protolith is virtually unfractured; there are very few joints in the rock that are not associated with faulting.

\section{Description of fault core}

Core zones for the main fault and the hanging-wall splay fault (labeled A, fig. A2) form resistant, slightly calcite-cemented, ribs on the outcrop. Fault slip surfaces typically bound one side of the resistant rib (fig. A3). The core zone for the main fault trace is 5-7 cm wide; the core zone for the splay is up to $2 \mathrm{~cm}$ wide. The fault cores consist of finely comminuted wall rock; grain size appears to be reduced. The protolith contains common $0.5-1-\mathrm{cm}$ pumice that is absent within the fault core; it is friable and has been comminuted into fault rock with average grain size of about $0.2 \mathrm{~mm}$.

\section{Description of damage zone}

The damage zone consists of three parts, labeled B and C (figs. A2 and A3)

B. A 30-centimeter-wide zone between the main fault and a hanging-wall splay with minor offset. The rock between these two faults is poorly consolidated and pervaded by centimeter-scale fracturing. Sigmoidal fractures cross this zone and connect the two fault planes.

C. A 1-m-wide zone of hanging-wall fractures that are spatially associated with the fault and subparallel to it. 


\section{Field station 05NTS1 - photographs}

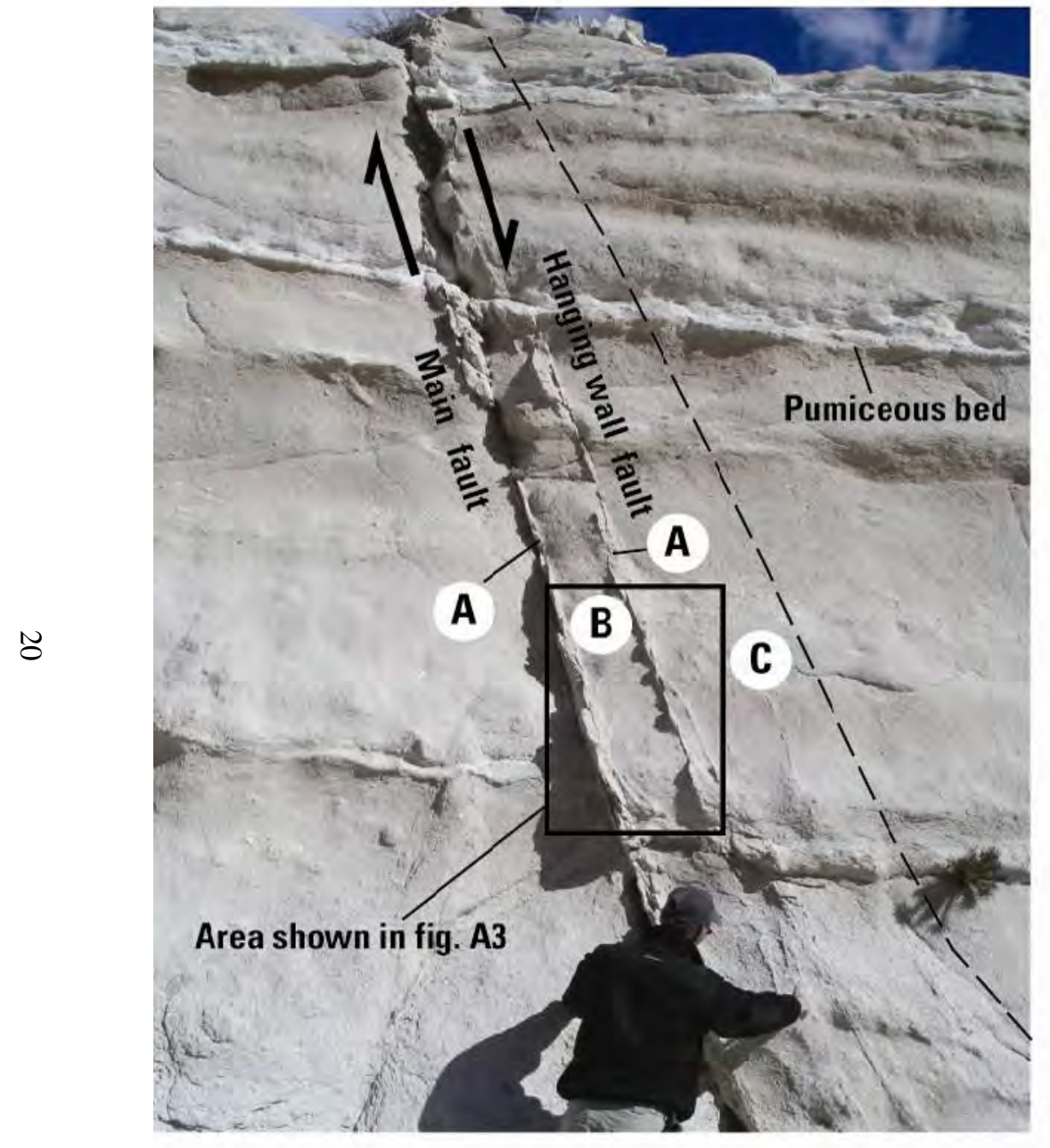

Figure A2. View, looking southeast, of faults in Calico Hills Formation, south of Rainier Mesa. Arrows show relative sense of offset. Fault core zones, labeled $A$, and fault-related damage zones, labeled $B$ and $C$, are described in the text. Dashed line marks the farthest extent of fault-related damage.

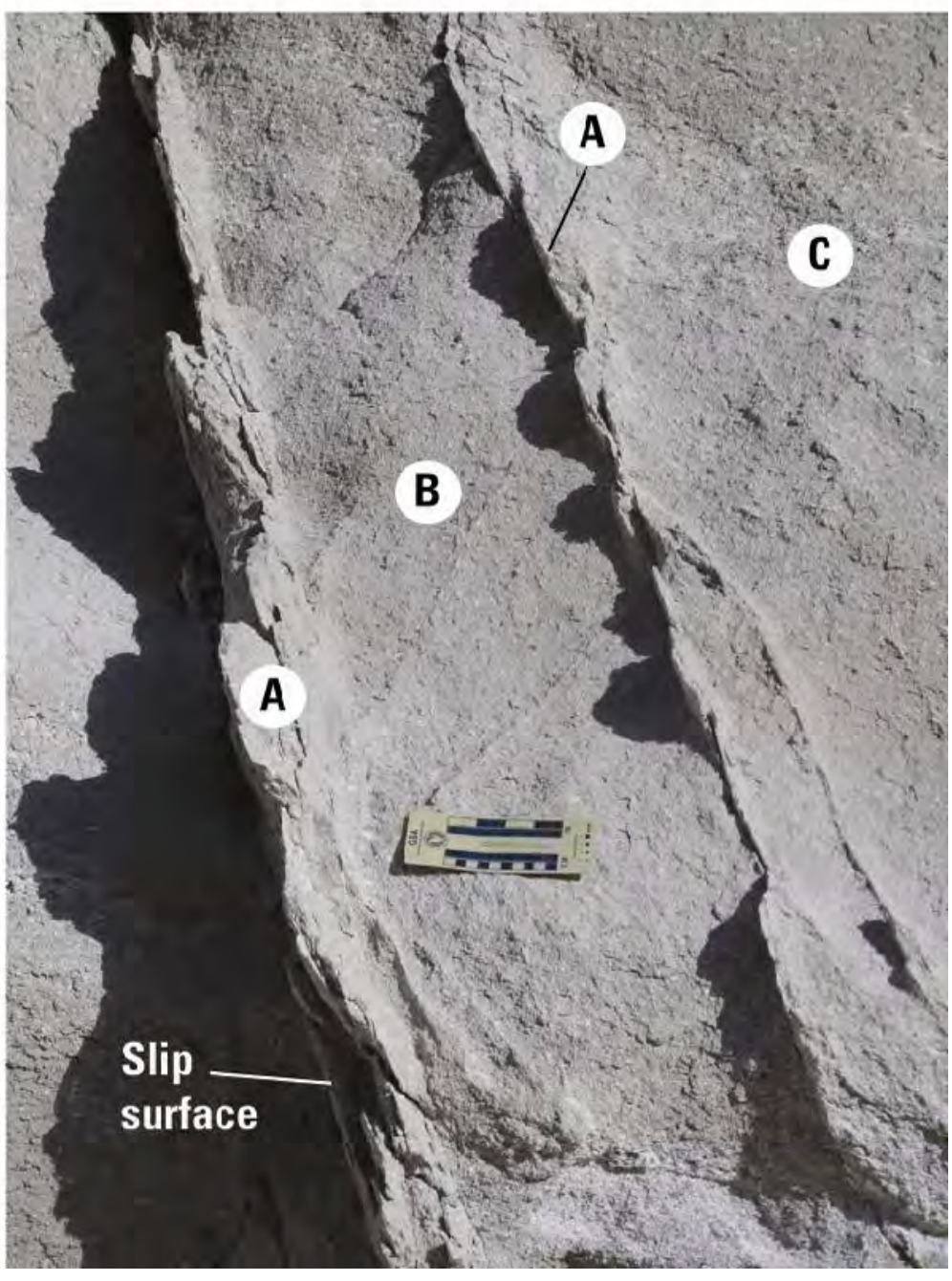

Figure A3. Detail of the fault zone showing the slip surface, fault core zones $(A)$, and the two fault-related damage zones ( $B$ and $\mathrm{C}$ ). Small subdivisions at the bottom edge of the scale are 1 centimeter. 


\section{Field station 05NTS2}

\section{Station description}

Station is located on the Tippipah Spring quadrangle (fig. A1). Station is in Redrock Valley to the west of the Eleana Range, in and near road cut on the Pahute Mesa Road at the west side of Redrock Valley.

Fault orientation $235^{\circ} / 65^{\circ} \mathrm{W}$. Two footwall splays to the east of the main fault trace are also steeply west-dipping (fig. A4).

\section{Sense of slip and amount of offset}

Main fault has about $12 \mathrm{~m}$ of down-to-west offset as measured in outcrop and reported on 1:24,000-scale geologic map (Orkild, 1963). The largest footwall splay has $2 \mathrm{~m}$ of down-to-west offset (fig. A4).

\section{Length of fault trace in map view}

Fault trace is about $3 \mathrm{~km}$ in length on 1:24,000-scale geologic map of the Tippipah Spring quadrangle (Orkild, 1963). Fault appears to have its maximum displacement near the field station and loses displacement to the north and south.

\section{Lithologic unit in hanging wall (HW) and footwall (FW)}

Rocks in the hanging wall are densely welded, devitrified tuff originally mapped as the Grouse Canyon Member of the Indian Trail Formation (Orkild, 1963); reinterpreted as Grouse Canyon Tuff of the Belted Range Group on the digital map of the NTS (Tbg of Slate and others, 2000). At the study location the footwall rocks are partly covered by talus but consist of bedded and nonwelded tuff and subordinate reworked tuff of the Tunnel Formation (Tn of Slate and others, 2000).

The protolith footwall rocks of the Tunnel Formation are relatively unfractured; there are very few joints in the rock that are not associated with faulting, especially in the pumiceous or reworked sections. The protolith hanging-wall rocks, densely welded Grouse Canyon Tuff, have a well-developed network of cooling joints that are long, smooth, and gently curved (labeled D, fig. A5). The joints form a three-dimensional network of vertical joints and gently undulating subhorizontal joints.

\section{Description of fault core}

The fault core along the main trace of fault is buried by talus and not exposed.

\section{Description of damage zone}

Footwall damage: To the northeast of the Pahute Mesa road, footwall damage in the Tunnel Formation forms a zone about $25 \mathrm{~m}$ wide, mostly as a result of a synthetic footwall splay with 2 $\mathrm{m}$ of offset and other, subsidiary splay faults (fig. A4). These faults result in a broad zone of fracturing and minor movement along a number of subparallel, discrete features. The intervening rock shows some block rotation but little fracturing. In a second exposure some $250 \mathrm{~m}$ to the south, footwall damage in the Tunnel Formation is much narrower. The rock is unfractured to within $5 \mathrm{~m}$ of the main fault trace, becoming granular and fragmented within a few meters of the fault. 


\section{Field station 05NTS2, continued}

Hanging wall damage: A wide damage zone is developed in the Grouse Canyon Tuff in the hanging wall of the main fault. The damage zone consists of three parts, labeled A, B, C (figs. A4 and A5):

A. A 5-m-wide zone immediately adjacent to the fault that is mostly covered; limited exposures show extensive clast-supported breccia of welded Grouse Canyon Tuff with rotated blocks less than $1 \mathrm{~m}$ in size.

B. A 25-m-wide zone of intense fracturing and minor faulting. Rock generally appears to be shattered in-place; locally, minor faults result in small offsets. However, in several places subhorizontal cooling joints can be traced in this zone with no offset. Zone is characterized by abundant fractures that pervade the rock mass and reduce the block size.

C. A 25-m-wide zone where hanging wall fractures that are spatially associated with the fault are present and increase overall fracture intensity above the background, but the rock mass is not shattered as in zone B. Some subhorizontal cooling joints (yellow lines, fig. A5) may be traced as relatively continuous features through the fault-related damage zones, indicating a general lack of fault offset within the damage zones. 


\section{Field station 05NTS2 - photographs}

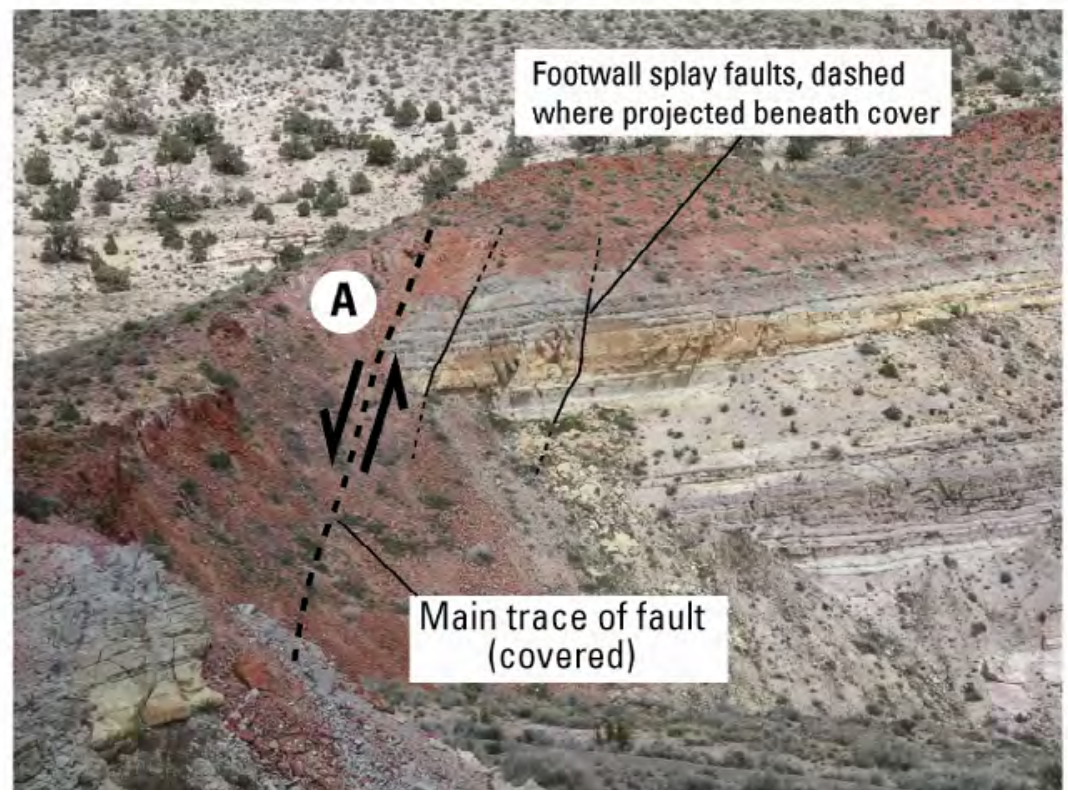

Figure A4. View, looking south, of fault in Redrock Valley that offsets red Grouse Canyon Tuff and underlying tan and grey beds of the Tunnel Formation. Main trace of fault is covered; approximate trace is shown by the dashed line with arrows showing relative sense of offset. Two minor splays in the footwall have the same sense of offset as the main fault. Hanging-wall fault-related damage zone $(A)$ is discussed in text. Field of view approximately 100 meters.

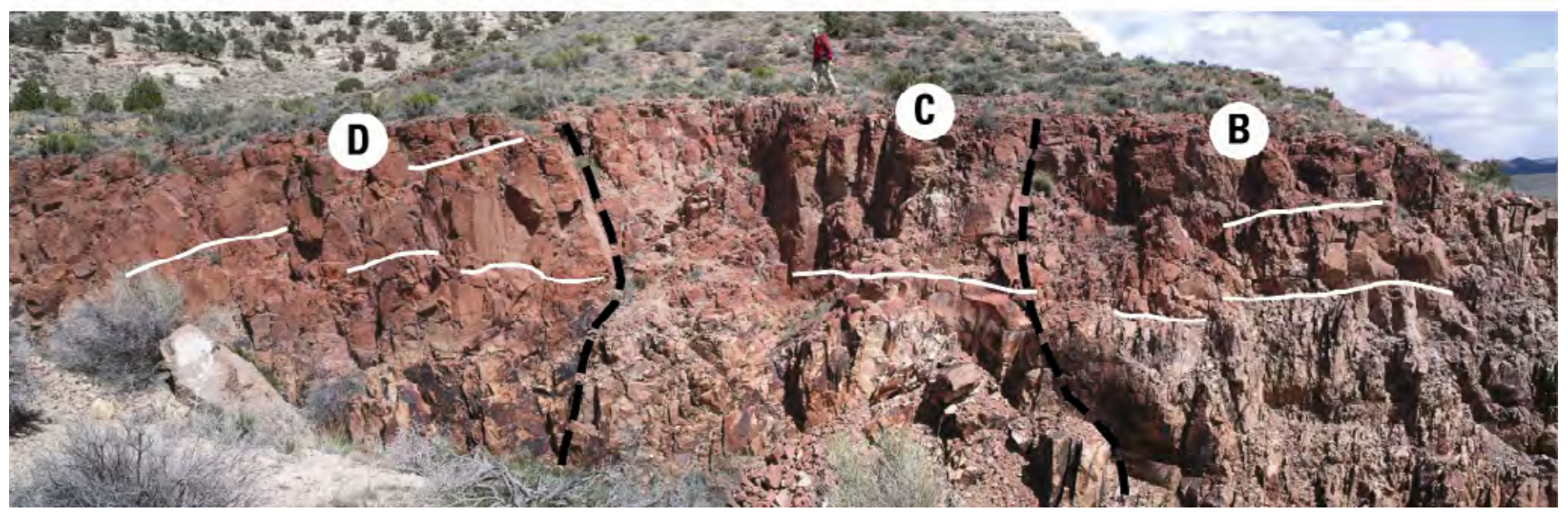

Figure A5. View, looking south, of fault-related deformation in the hanging wall. Geologist walking above the outcrop for scale. Trace of the fault shown in figure A4 is off the east (right) side of the photo. Boundaries between fault-related damage zones, labeled $B$ and $C$, and protolith, labeled $D$, are shown by thick dashed lines. Thin white lines mark the trace of subhorizontal cooling joints. 


\section{Field station 05NTS3}

\section{Station description}

Station is located on the Tippipah Spring quadrangle (fig. A1). Station is south of the Buckboard Mesa Road in broad, low outcrops of the Tunnel Formation to the west of Tippipah Spring.

Fault orientation Numerous minor faults are present, some are portrayed as joints on the 1:24,000-scale geologic map of the Tippipah Spring quadrangle (Orkild, 1963). Faults with more than $1 \mathrm{~m}$ of offset generally strike north and dip steeply (about $80^{\circ}$ to the east). Minor faults, especially common as linking or relay structures between the north-striking faults, strike northeast and are subvertical. The entire outcrop is essentially a mesh of interrelated north- and northeast-striking faults (fig. A6).

\section{Sense of slip and amount of offset}

North-striking faults have normal, east-side-down displacement with stratigraphic offsets of $3 \mathrm{~m}$ or less.

\section{Length of fault trace in map view}

The longest of the north-striking faults has a map trace of about $1.5 \mathrm{~km}$ in length on 1:24,000scale geologic map (Orkild, 1963). Many of the faults are less than $1 \mathrm{~km}$ in length.

\section{Lithologic unit in hanging wall (HW) and footwall (FW)}

Both HW and FW are in bedded and nonwelded tuff, pumiceous airfall and subordinate reworked tuff originally mapped as the Lower Member of the Indian Trail Formation (Orkild, 1963); reinterpreted as the Tunnel Formation on the digital map of the NTS (Tn of Slate and others, 2000).

\section{Description of fault core}

Fault cores were not observed in outcrop on any of the north-striking faults. If present, core zones must be exceedingly thin $(<1 \mathrm{~mm})$.

\section{Description of damage zone}

Two types of fault damage effects were noted at several of the north- and northeast-striking faults in this vicinity:

(1) In pumiceous airfall units, the main effect is a distributed granulation. The rock becomes less cohesive but without any obvious fractures.

(2) In the nonwelded tuff units, minor fractures that are subparallel to the faults form damage zones 30-60 centimeter wide on either side of the fault. 


\section{Field station 05NTS3 - photograph}

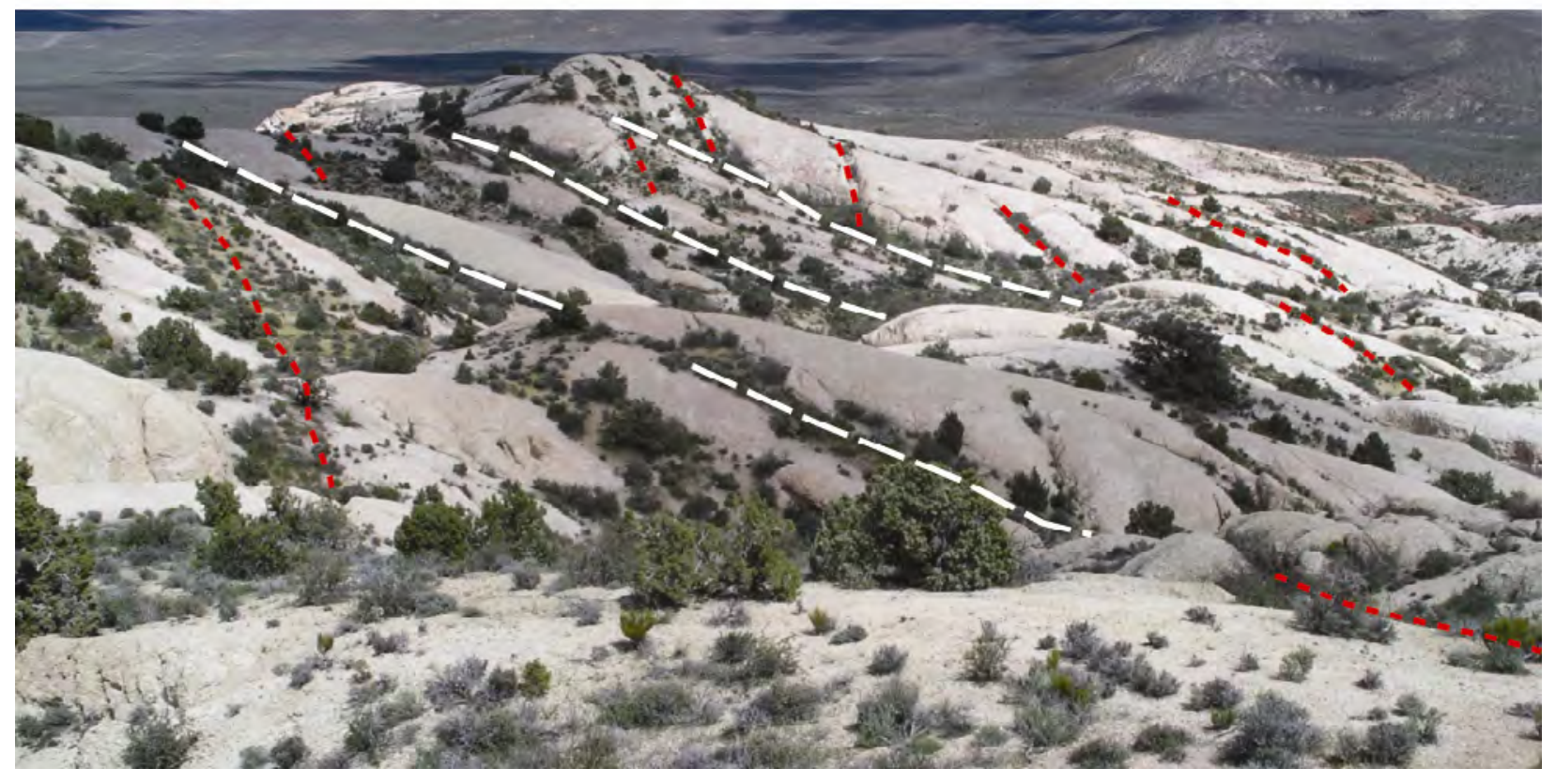

Figure A6. View looking northeast of minor faults within nonwelded tuff of the Tunnel Formation. Northstriking faults (white long-dashed lines) typically have between 1 and $5 \mathrm{~m}$ of offset and are linked by northeaststriking faults (red short-dashed lines). Field of view approximately 100 meters. 


\section{Field station 05NTS4}

\section{Station description}

Station is located on the Tippipah Spring quadrangle (fig. A1). Station is south of the Buckboard Mesa Road in narrow north-trending canyon immediately north of Tippipah Point at the north end of Shoshone Mountain.

Fault orientation At the station location in the narrowest part of the canyon, the fault strikes north and dips $80^{\circ} \mathrm{E}$. To the south, the fault bends to the southeast and is oriented $025^{\circ} / 80^{\circ} \mathrm{E}$. (Orkild, 1963).

\section{Sense of slip and amount of offset}

The fault has $55 \mathrm{~m}$ of normal, east-side-down displacement, shown by stratigraphic offset of the Lithic Ridge Tuff.

\section{Length of fault trace in map view}

The fault was traced continuously over a map distance of $1 \mathrm{~km}$ where it swings to a northeast strike and splits into several strands within poorly exposed Paintbrush Group rocks. The fault is depicted as having a continuous map trace of about $3 \mathrm{~km}$ in length on the 1:24,000-scale geologic map of the Tippipah Spring quadrangle (Orkild, 1963).

\section{Lithologic unit in hanging wall (HW) and footwall (FW)}

The FW is mostly in nonwelded tuff originally mapped as the Lower Member of the Indian Trail Formation (Orkild, 1963); reinterpreted as the Tunnel Formation on the digital map of the NTS (Tn of Slate and others, 2000). FW also includes the overlying Lithic Ridge Tuff. Hanging-wall rocks are nonwelded Bullfrog Tuff (Slate and others, 2000). Both units have networks of widely spaced joints.

\section{Description of fault core}

Fault core is a 2-5-mm-wide zone of very finely comminuted rock (fig. A7). Area was moist to touch when visited, fault rock appears to be slightly clayey.

\section{Description of damage zone}

The main slip plane is adjacent to the hanging wall. The hanging-wall rocks show a relative increase in fracturing within $2 \mathrm{~m}$ of the fault. Within $20 \mathrm{~cm}$ of the fault the rock becomes less cohesive without any obvious fractures. Present in the footwall is a damage zone about $30 \mathrm{~cm}$ wide of disaggregated and comminuted tuff (fig. A7); pumice fragments are still visible within this zone. This footwall zone appears to contain additional slip planes, although amount of offset is difficult to determine. Outside of this zone is a 3-m-wide zone of increased fracturing.

Nearby, two north-striking strands of this fault form a stepover or relay structure (fig. A8). The nonwelded tuff between the fault strands is shattered into decimeter-sized fragments. 


\section{Field station 05NTS4 - photographs}

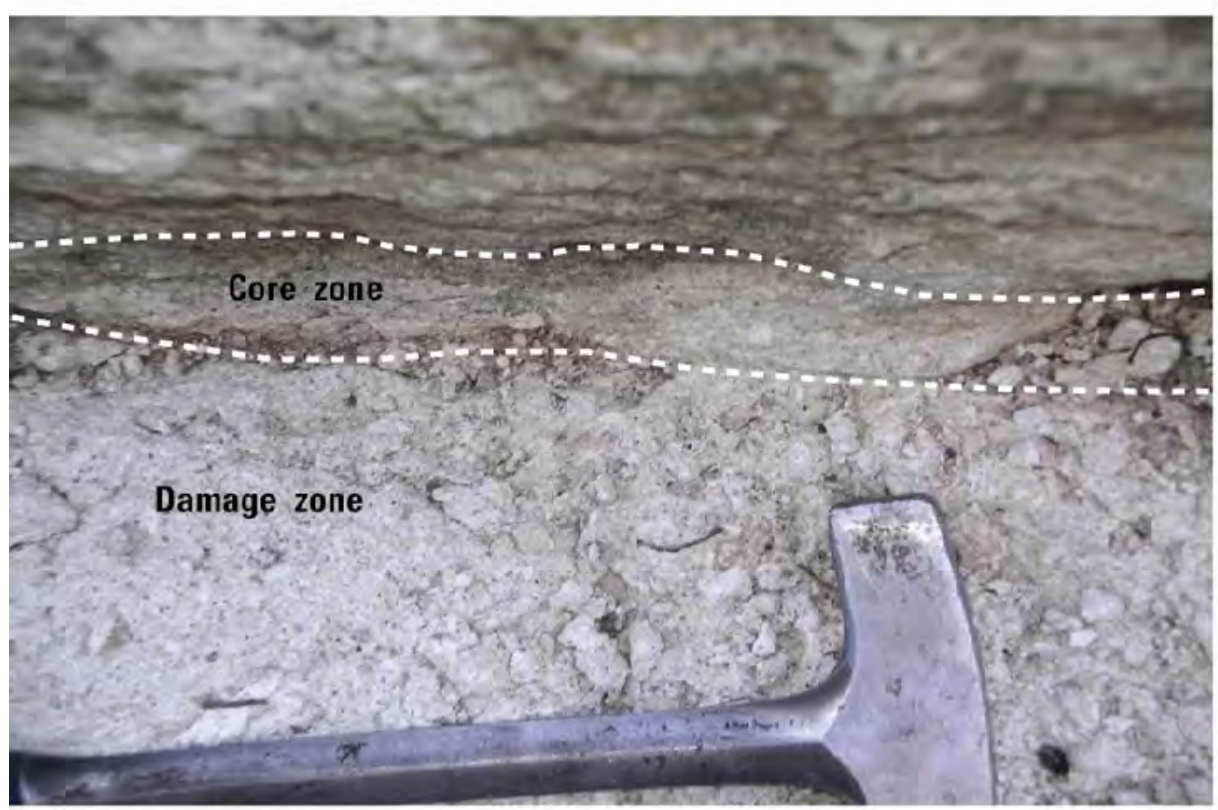

Figure A7. Detail of fault zone in nonwelded pumiceous tuff at north end of Shoshone Mountain. Dashed white lines separate fault core zone from surrounding fault-related damage zone.

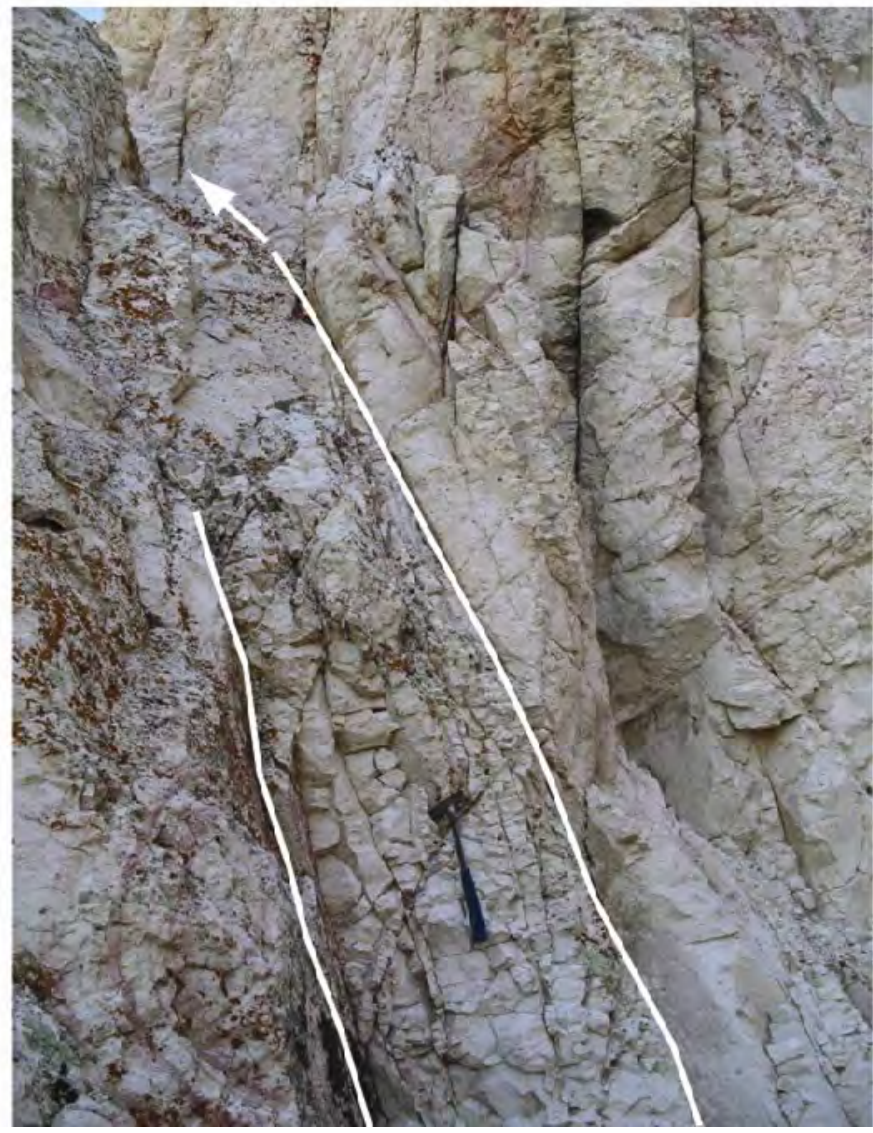

Figure A8. View of stepover between two normal fault strands (white lines), showing decimeter-scale fracturing between the two faults. Fault on the right crosses through a saddle at the top of the outcrop and continues upslope on the far side of the outcrop, as shown by the white arrow. 


\section{Field station 05NTS5}

\section{Station description}

Station is located on the Rainier Mesa quadrangle (fig. A1). Station is south of the Stockade Wash Road and north of Pinyon Butte.

\section{Fault orientation $315^{\circ} / 85^{\circ} \mathrm{W}$.}

\section{Sense of slip and amount of offset}

The fault has normal, west-side-down displacement with stratigraphic offset of about $100 \mathrm{~m}$ of the top of the Bullfrog Tuff (Gibbons and others, 1963).

\section{Length of fault trace in map view}

The fault can be traced continuously over a map distance of at least $9 \mathrm{~km}$ across the southwestern part of the Rainier Mesa 1:24,000-scale geologic map (Gibbons and others, 1963), although several abrupt apparent bends in the fault trace may actually be stepovers between parallel fault strands.

\section{Lithologic unit in hanging wall (HW) and footwall (FW)}

The HW is densely welded, devitrified tuff originally mapped as the Topopah Spring Member of the Piapi Canyon Formation (Gibbons and others, 1963); reinterpreted as Topopah Spring Tuff on the digital map of the NTS (Slate and others, 2000). HW welded tuff has a network of cooling joints with generally meter-scale spacing where not affected by faults. Footwall rocks are massive, weakly welded tuff originally mapped as the Stockade Wash Member of the Piapi Canyon Formation (Gibbons and others, 1963); reinterpreted as Bullfrog Tuff on the digital map of the NTS (Slate and others, 2000).

\section{Description of fault core}

A fault core was not observed in outcrop. If present, core zones must be exceedingly thin $(<1$ millimeter).

\section{Description of damage zone}

In the hanging wall, a 1-m-wide zone of clast-supported breccia abuts an erosional scarp adjacent to the fault plane (fig. A9). The breccia consists of subangular, 1-cm fragments of Topopah Spring Tuff exclusively in a sandy tuffaceous matrix. Hanging wall rocks appear to be affected by the fault for an additional $5 \mathrm{~m}$ outside of this breccia zone, as shown by decreased block size in relation to unfaulted rock and the presence of minor slip planes. The footwall is covered for a 5-m interval away from the fault, beyond which is unfractured Bullfrog Tuff. 


\section{Field station 05NTS5 - photograph}

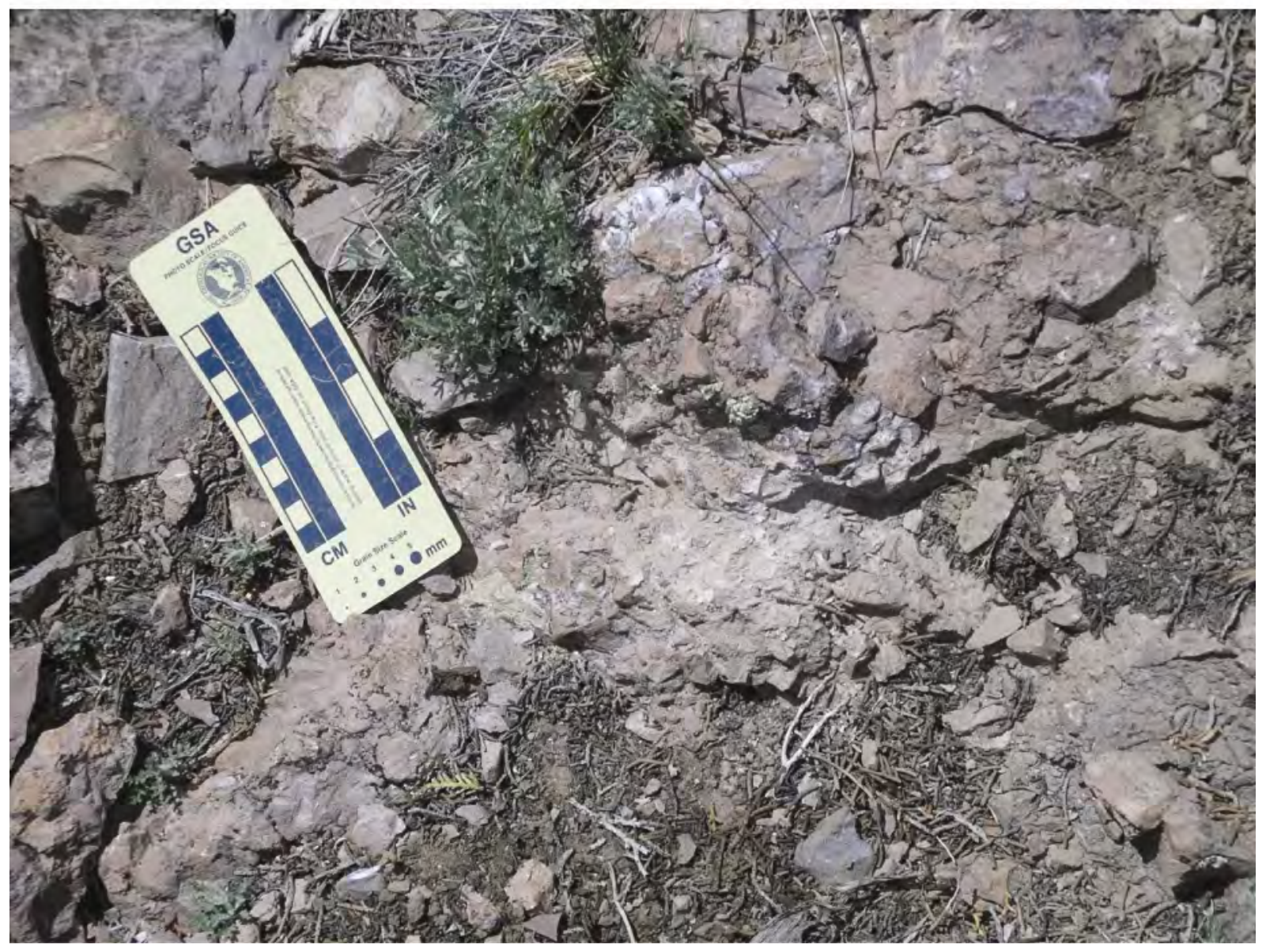

Figure A9. Detail of clast-supported breccia consisting of 1-centimeter angular fragments of hanging-wall Topopah Spring Tuff. Breccia forms a zone $1 \mathrm{~m}$ wide in hanging wall of the fault. 


\section{Field station 06NTS1}

\section{Station description}

Station is located on the Rainier Mesa quadrangle (fig. A1). Station is near the portal of the USGS tunnel, about $50 \mathrm{~m} \mathrm{WSW}$ and $15 \mathrm{~m}$ above the portal.

Fault orientation $190^{\circ} / 57^{\circ} \mathrm{W}$. The fault is slightly undulatory; dip is locally as shallow as $45^{\circ}$.

\section{Sense of slip and amount of offset}

The fault has normal, west-side-down displacement (fig. A10) with stratigraphic offset of about between 3 and $5 \mathrm{~m}$, based on offsets of marker beds (Plate 3 of Hansen and others, 1963). Displacement is near a maximum at the station location and diminishes in either direction.

\section{Length of fault trace in map view}

The fault has a map trace of about $250 \mathrm{~m}$ (Plate 3 of Hansen and others, 1963).

\section{Lithologic unit in hanging wall (HW) and footwall (FW)}

Both HW and FW are in zeolitically altered bedded and nonwelded tuff, pumiceous airfall and subordinate reworked tuff originally mapped as the Lower Member of the Indian Trail Formation (Gibbons and others, 1963); reinterpreted as the Tunnel Formation on the digital map of the NTS (Tn of Slate and others, 2000). Individual beds are typically 2-3 m thick. Where the units are unfaulted, fractures are spaced 1-2 m apart and span the thickness of a bed but typically truncate at the top and bottom of each bed.

\section{Description of fault core}

The fault core is a 1-2-cm zone adjacent to the slip plane (A, fig. A11). This zone is made up of finely comminuted material that is sandy, not clayey. This material is penetrated by numerous centimeter-scale sigmoidal fractures that may be slip surfaces as well; these surfaces subdivide the comminuted material into lens-shaped bodies $0.5 \mathrm{~cm}$ long.

\section{Description of damage zone}

In the hanging wall, a 30-centimeter-wide zone of fracturing lies outside of the core zone (B, fig. A11). Fractures are closely spaced, slightly anastamosing, sigmoidal, and up to $50 \mathrm{~cm}$ long. These fractures are systematically oriented at about 30 degrees to the slip plane (B, fig. A11). Outside of this is a 3-4-m-wide zone of blocky fracturing (C, fig. A10) with higher fracture intensity than the adjacent protolith. Fractures in this zone still appear to be related to the fault and are 1-2 $\mathrm{m}$ in length with spacing of 30 to $60 \mathrm{~cm}$ (fig. A10). Some of these fractures may be related to two hanging-wall splays that are about $5 \mathrm{~m}$ to the west of the main fault trace. Footwall rocks display decimeter-scale fracturing within $0.5 \mathrm{~m}$ of the fault plane. Beyond this, footwall rocks are covered by talus for a distance of $2 \mathrm{~m}$. 


\section{Field station 06NTS1 - photographs}

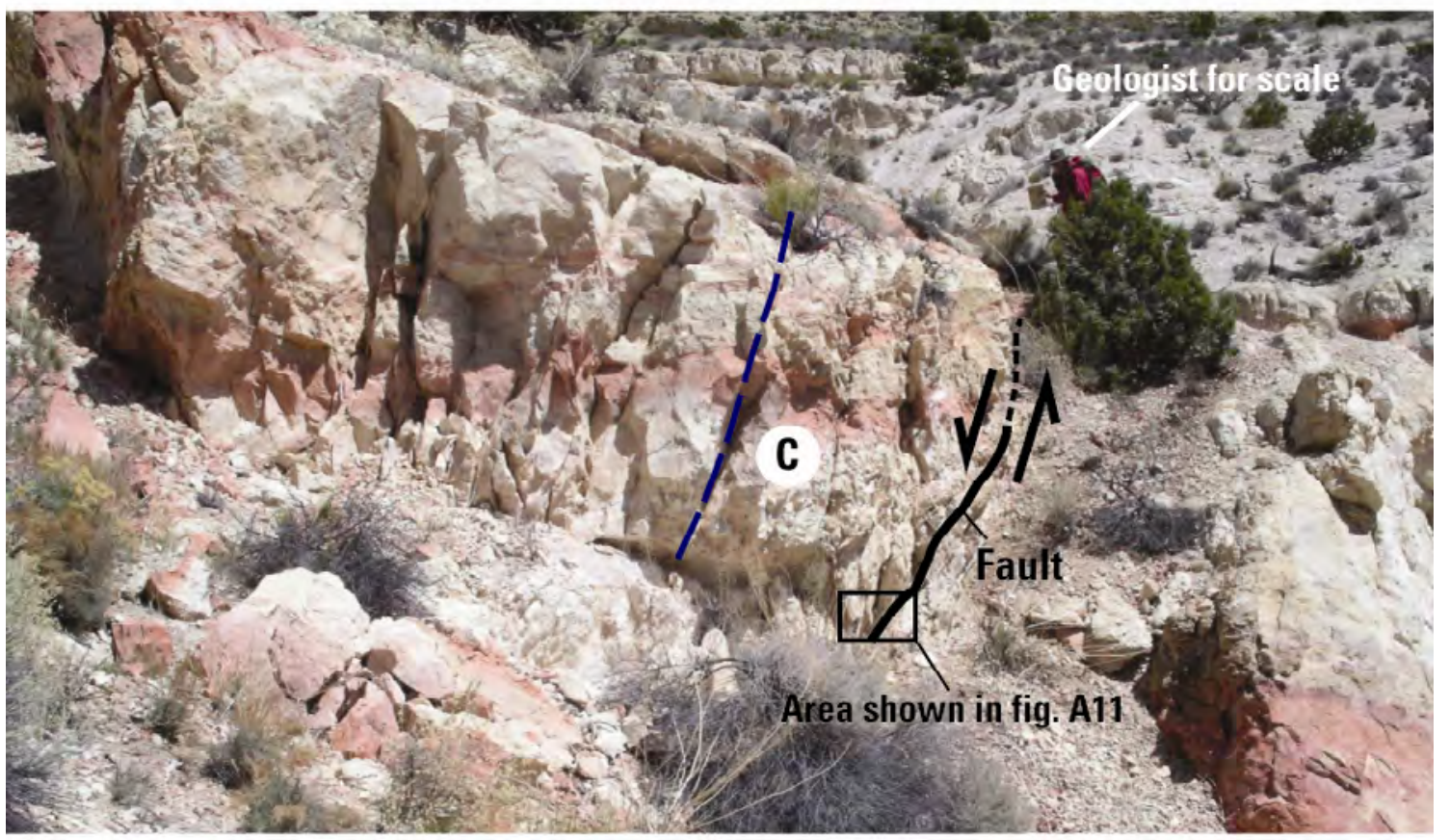

Figure A10. View, looking north, of fault in zeolitized Tunnel Formation. Fault is shown by black line, short dashed line where projected beneath cover. Arrows show relative sense of offset on the fault. Blue long-dashed line marks the farthest extent of fault-related damage, which extends into hanging wall about 3 meters as a zone of increased fracture intensity (labeled C).

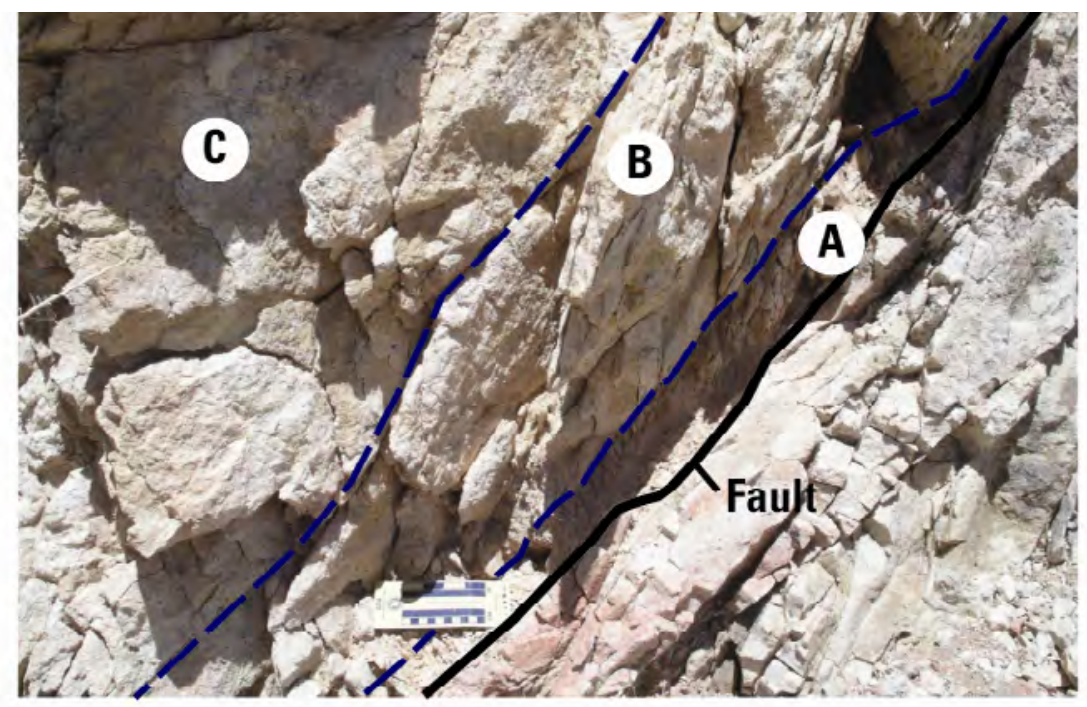

Figure A11. Detail of fault in zeolitized Tunnel Formation showing the fault and three faultrelated damage zones in the hanging wall (labeled A, B, and C). Blue long-dashed lines show the interpreted boundaries between the different fault damage zones. Small subdivisions at the bottom edge of the scale are 1 centimeter. 


\section{Field station 06NTS2}

\section{Station description}

Station is located on the Rainier Mesa quadrangle (fig. A1). Station is southeast of Rainier Mesa, to the north of the Stockade Wash road.

Fault orientation $015^{\circ} / 55^{\circ} \mathrm{W}$.

\section{Sense of slip and amount of offset}

The fault has normal, west-side-down displacement with stratigraphic offset of about between 2 and $5 \mathrm{~m}$, although there are few stratigraphic markers within the massive nonwelded tuff (fig. A12) to define offset more confidently.

\section{Length of fault trace in map view}

The fault has a map trace of about $1 \mathrm{~km}$ (Gibbons and others, 1963).

\section{Lithologic unit in hanging wall (HW) and footwall (FW)}

Both HW and FW are in thickly bedded nonwelded tuff originally mapped as the Lower Member of the Indian Trail Formation (Gibbons and others, 1963), reinterpreted as the Tunnel Formation on the digital map of the NTS (Tn of Slate and others, 2000).

\section{Description of fault core}

No fault core was observed in outcrop. If present, core zones must be exceedingly thin $(<1 \mathrm{~mm})$.

\section{Description of damage zone}

The rock in both the hanging wall and footwall is affected in a zone about $0.5 \mathrm{~m}$ wide by a weak but pervasive fabric of anastamosing, generally north-striking fractures (fig. A13). Fractures are discontinuous and as long as $1 \mathrm{~m}$, although most are about $10 \mathrm{~cm}$ in length. 


\section{Field station 06NTS2 - photographs}

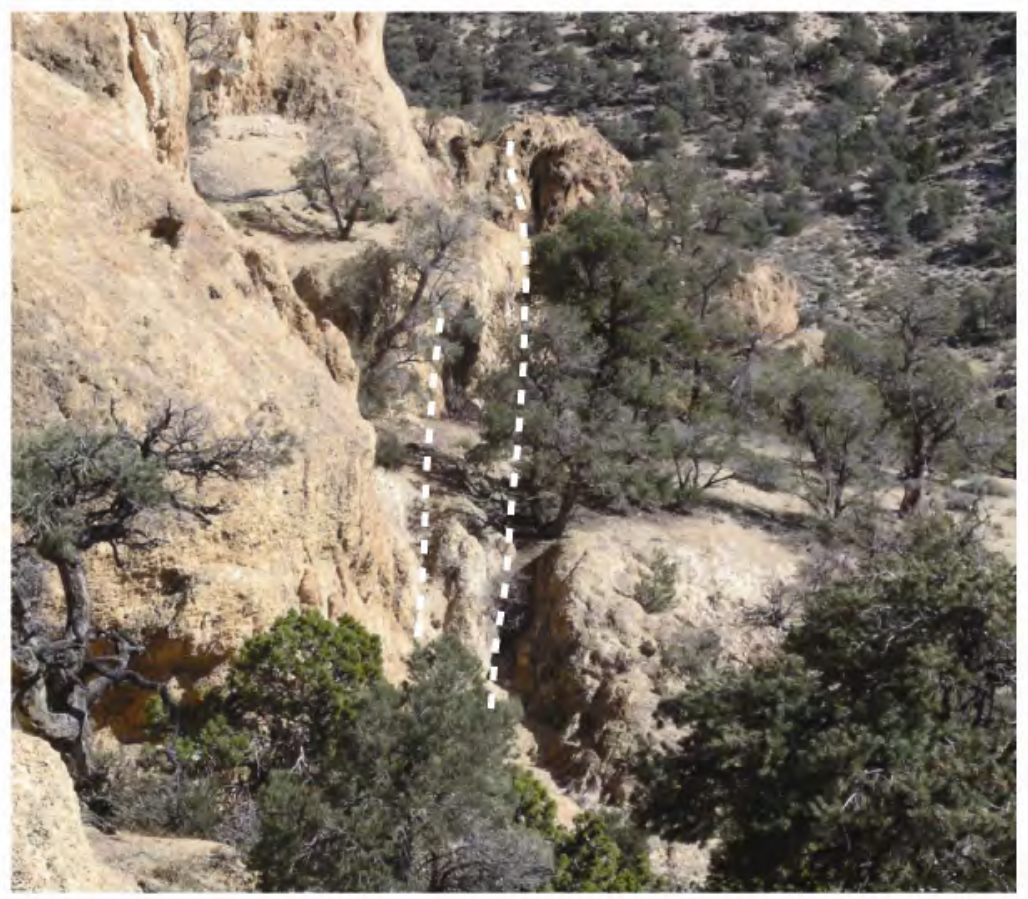

Figure A12. View, looking south, of faults in massive, pumiceous nonwelded tuff of the Tunnel Formation. Faults are mostly covered (dashed white lines) and tend to form shallow erosional aullies.

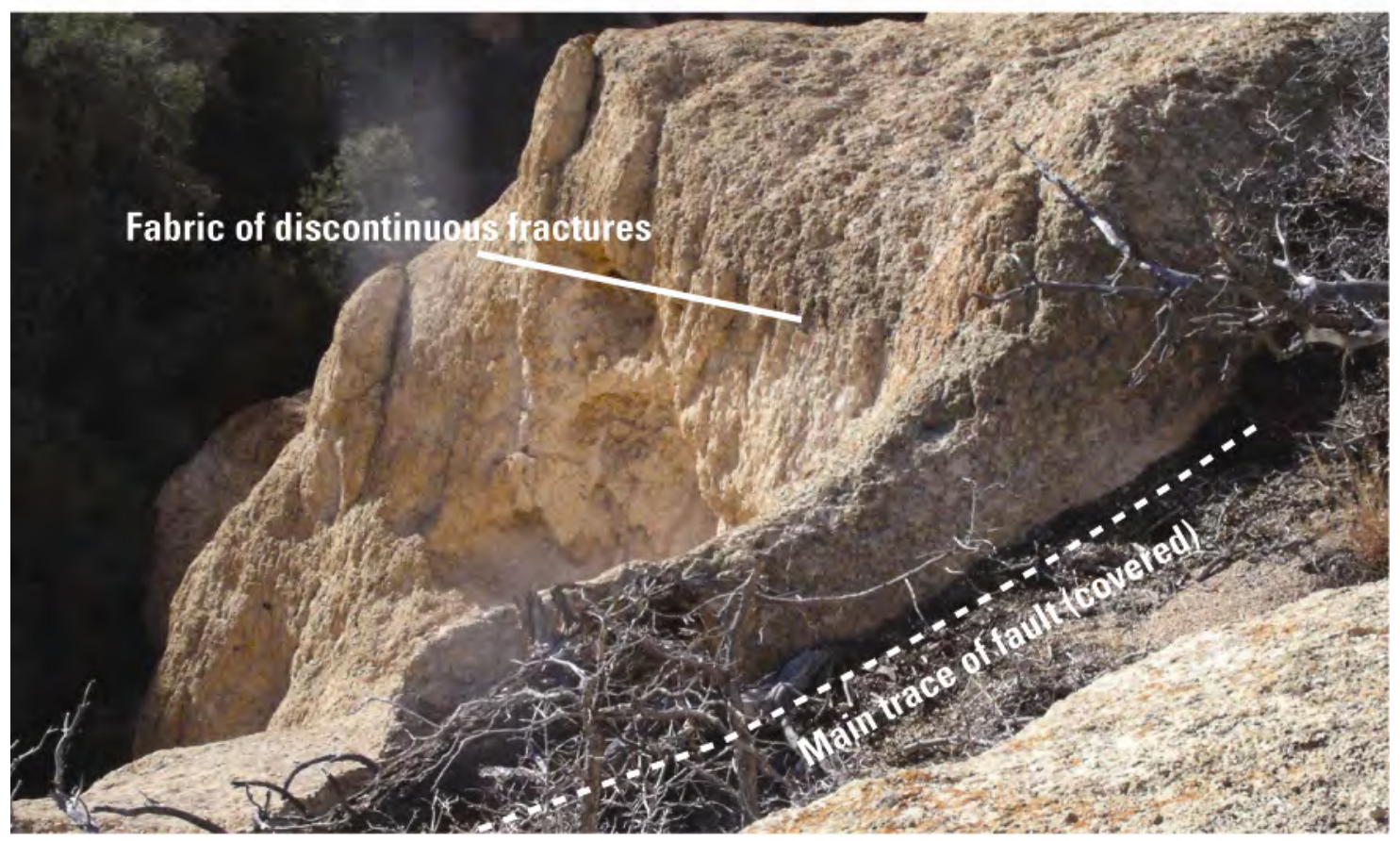

Figure A13. Detail of fault in Tunnel Formation. Rocks on either side of the fault are affected by a weak but pervasive fabric of small, north-striking fractures. 


\section{Field station 06NTS3}

\section{Station description}

Station is located on the Rainier Mesa quadrangle (fig. A1). Station is on eastern flank of Rainier Mesa, to the west of the Stockade Wash road.

\section{Fault orientation $190^{\circ} / 80^{\circ} \mathrm{W}$.}

\section{Sense of slip and amount of offset}

The fault has normal, west-side-down displacement with stratigraphic offset of about $30 \mathrm{~m}$ based on offsets of distinctive marker beds (Gibbons and others, 1963). This fault branches upward and becomes several small strands as it climbs towards the Timber Mountain Group rocks that cap Rainier Mesa.

\section{Length of fault trace in map view}

The fault has a map trace of about $1.5 \mathrm{~km}$ (Gibbons and others, 1963). This is the longest fault with the greatest amount of offset of the faults that cut the east face of Rainier Mesa. This is the only fault that is mapped across the top of Rainier Mesa to the northwest flank (Gibbons and others, 1963).

\section{Lithologic unit in hanging wall (HW) and footwall (FW)}

At this field location, both HW and FW are in thick, nonwelded tuff originally mapped as the Lower Member of the Indian Trail Formation (Gibbons and others, 1963); reinterpreted as the Tunnel Formation on the digital map of the NTS (Tn of Slate and others, 2000).

\section{Description of fault core}

No fault core was observed in outcrop. Main trace of fault is covered by an interval of talus between 1 and $5 \mathrm{~m}$ wide (fig. A14).

\section{Description of damage zone}

Bed of massive white nonwelded tuff in the hanging wall can be traced to the talus interval and displays no fracturing or fault influence. In the footwall, pumiceous nonwelded tuff forms a low cliff and displays a weak fabric of fault-parallel fractures within a zone $2 \mathrm{~m}$ wide adjacent to the covered fault (A, fig. A14). Fractures in this zone are 10-20 cm in length and have an average spacing of about $4 \mathrm{~cm}$. 


\section{Field station 06NTS3 - photograph}

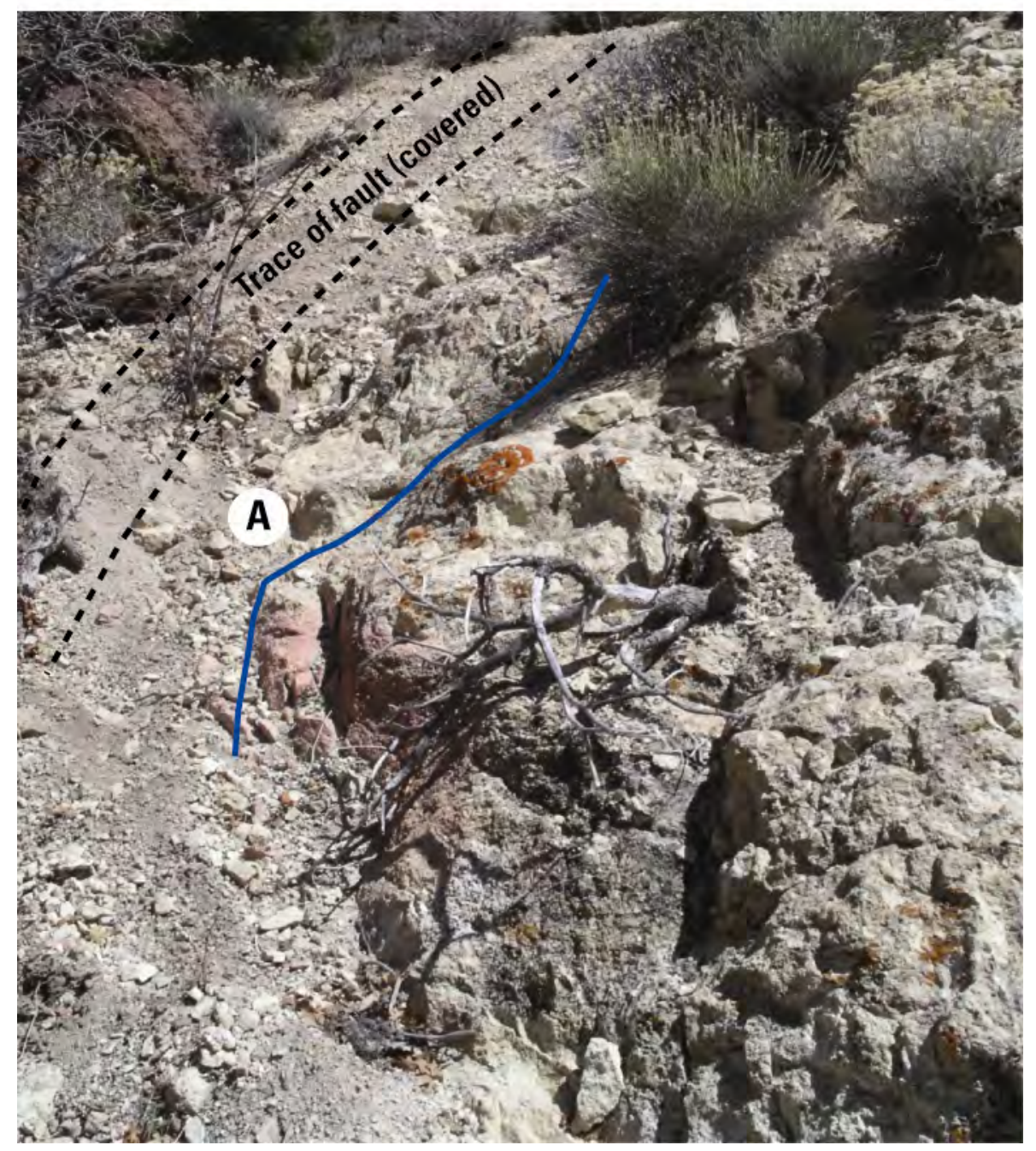

Figure A14. View of fault zone on eastern flank of Rainier Mesa. Fault trace is covered but locally confined by outcrop to a 1-m-wide interval, shown by the dashed lines. Blue line marks the farthest extent of fault-related damage (labeled $\mathrm{A}$ in the figure). 


\section{Field station 06NTS4}

\section{Station description}

Station is located on the Rainier Mesa quadrangle (fig. A1). Station is on eastern flank of Rainier Mesa, to the west of the Stockade Wash road.

Fault orientation $190^{\circ} / 75^{\circ} \mathrm{W}$.

\section{Sense of slip and amount of offset}

The fault has reverse, west-side-up displacement with stratigraphic offset of about $2 \mathrm{~m}$ (fig. A15). This fault is a minor splay or relay within the system of faults in this vicinity, including field station 06NTS3.

\section{Length of fault trace in map view}

Fault is not shown on 1:24,000-scale geologic map (Gibbons and others, 1963). Fault trace may not be longer than about $60 \mathrm{~m}$ based on field observations.

\section{Lithologic unit in hanging wall (HW) and footwall (FW)}

At this field location, both HW and FW are in pumiceous, nonwelded tuff originally mapped as the Lower Member of the Indian Trail Formation (Gibbons and others, 1963); reinterpreted as the Tunnel Formation on the digital map of the NTS (Tn of Slate and others, 2000).

\section{Description of fault core}

No fault core was observed in outcrop. Trace of fault is covered by an interval of talus about 0.5 m wide.

\section{Description of damage zone}

Footwall displays a damage zone about $2 \mathrm{~m}$ wide, consisting of fault-parallel fractures with a spacing of 10-15 cm. Hanging wall does not display any fault-related fabric. 


\section{Field station 06NTS4 - photograph}

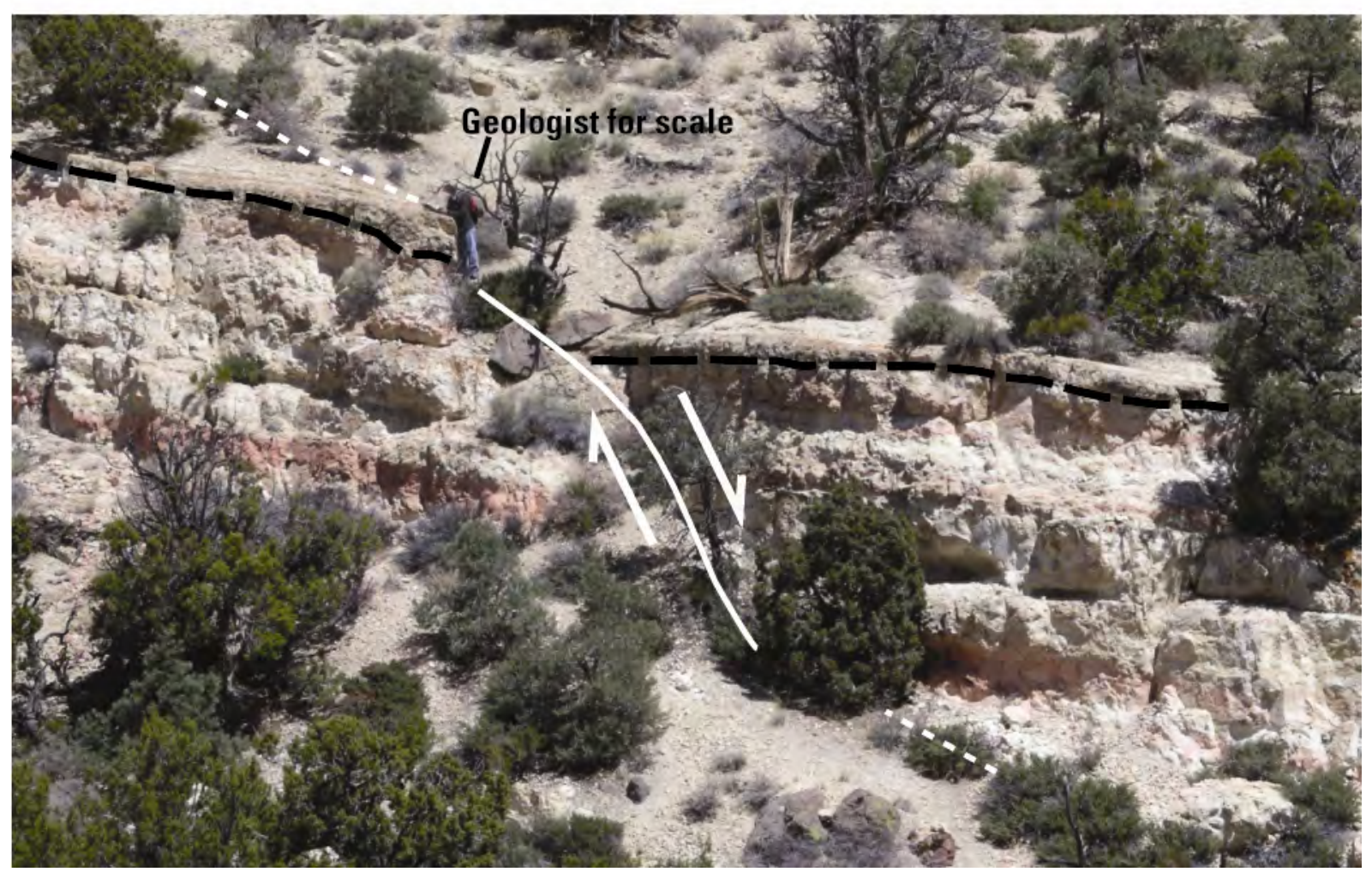

Figure A15. View of fault in Tunnel Formation on east flank of Rainier Mesa. Fault is shown as solid line where exposed in bedrock, dashed where projected beneath cover. Arrows show relative sense of displacement. Thick long-dashed lines indicate the base of a distinctive gravel marker bed used to measure offset on the fault. 


\section{Field station 06NTS5}

\section{Station description}

Station is located on the Rainier Mesa quadrangle (fig. A1). Station is on eastern flank of Rainier Mesa, to the west of the Stockade Wash road. Station is located near the intersection of two normal faults. Station is southwest of, and in footwall of, a WNW-striking, down-to-thenortheast normal fault (fig. A16) close to where the fault is intersected by the NW-striking, down-to-the southwest fault that was described at station 06NTS3.

Fault orientation $120^{\circ} / 80^{\circ} \mathrm{W}$.

\section{Sense of slip and amount of offset}

The fault has a maximum of about $30 \mathrm{~m}$ of normal, northeast-side-down displacement, based on stratigraphic offset of marker beds within the Tunnel Formation.

\section{Length of fault trace in map view}

The fault has a map trace of about $1.5 \mathrm{~km}$ (Gibbons and others, 1963).

\section{Lithologic unit in hanging wall (HW) and foot wall (FW)}

Both HW and FW are in bedded and nonwelded tuff, pumiceous airfall and subordinate reworked tuff originally mapped as the Lower Member of the Indian Trail Formation (Gibbons and others, 1963); reinterpreted as the Tunnel Formation on the digital map of the NTS (Tn of Slate and others, 2000).

\section{Description of fault core}

No fault core was observed in outcrop. Main trace of fault is covered in the wash bottom by an interval of talus about $5 \mathrm{~m}$ wide (fig. A17).

\section{Description of damage zone}

Only the hanging wall is exposed at this station. The 5-m-wide hanging-wall damage zone (fig. A17) consists of fractures 1.5-2 m high that are subparallel to the fault but dip steeply to the northeast, into the fault plane. Fracture spacing within this zone is about $5 \mathrm{~cm}$. Beyond this damage zone, the rock is massive and generally unfractured. Red and white layering (fig. A17) indicates that few of these fractures have any offset. Fractures within the damage zone terminate at a pumiceous, nonwelded tuff near the base of the outcrop (fig. A17). 


\section{Field station 06NTS5 - photographs}

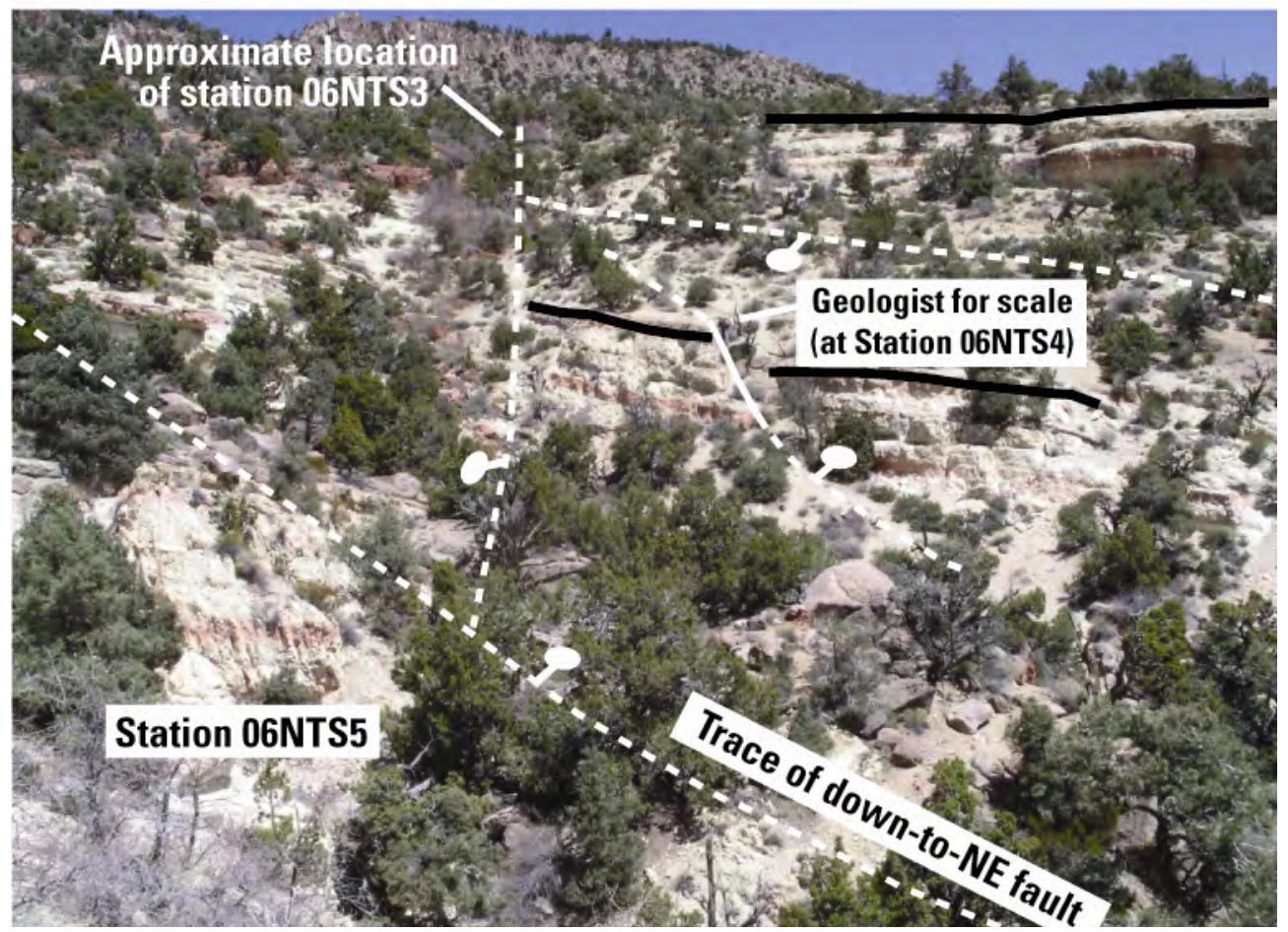

Figure A16. View, looking northwest of faults in Tunnel Formation on east flank of Rainier Mesa. Faults are shown as solid lines where exposed in bedrock, dashed lines where projected beneath cover. Ball and bars are on downthrown sides of faults and show relative sense of displacement. Thick black lines indicate the base of a distinctive gravel marker bed used to measure offset on the faults. Field stations 06NTS4 and 06NTS5 are visible.

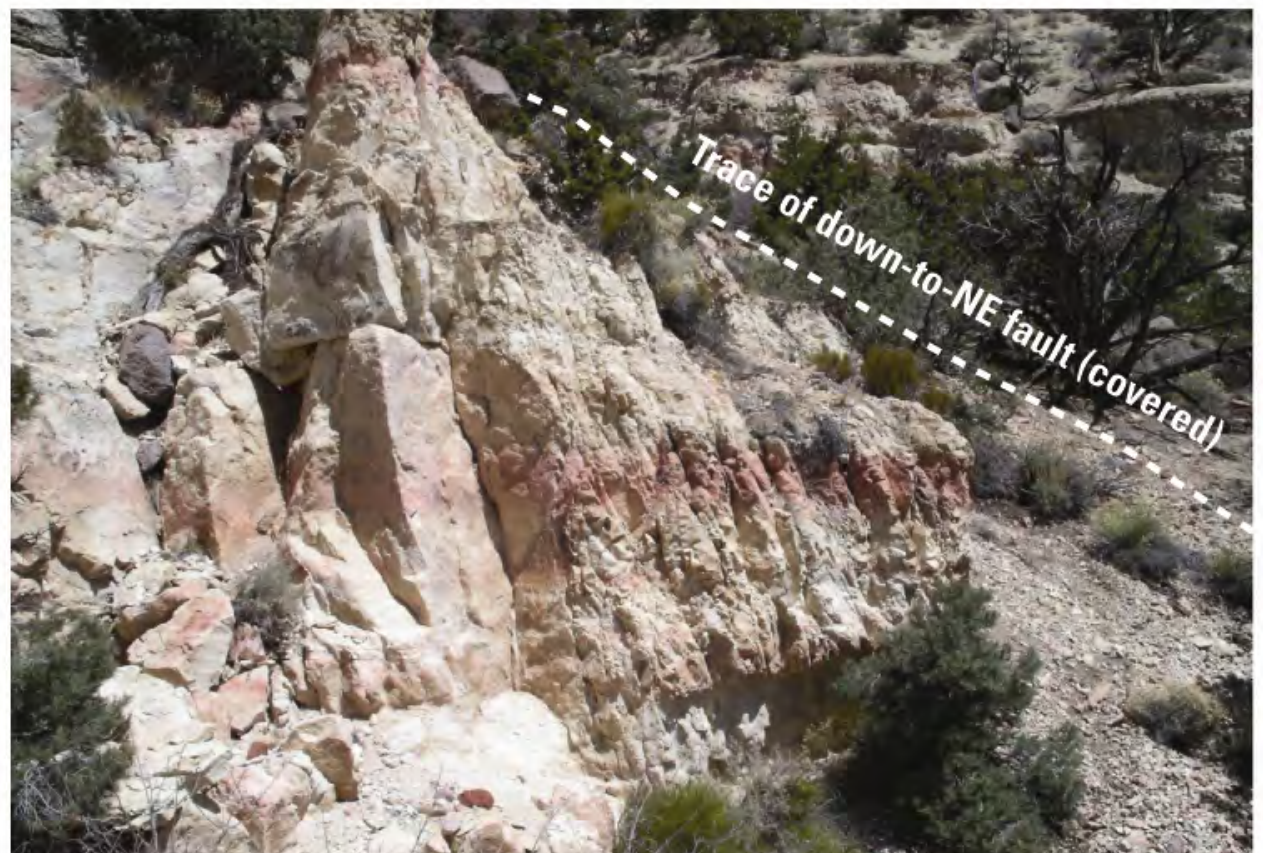

Figure A17. Detail of fracturing present in hanging-wall rocks at station 06NTS5. 


\section{Field station 06NTS6}

\section{Station description}

Station is located on the Rainier Mesa quadrangle (fig. A1). Station is on eastern flank of Rainier Mesa, to the west of the Stockade Wash road. Station is downhill and slightly east of 06NTS5.

Fault orientation $165^{\circ} / 77^{\circ} \mathrm{W}$.

\section{Sense of slip and amount of offset}

The fault has normal, west-side-down displacement with stratigraphic offset of about $1 \mathrm{~m}$, based on offset of dark red marker bed (fig. A18).

\section{Length of fault trace in map view}

Fault is not shown on 1:24,000-scale geologic map (Gibbons and others, 1963). Fault trace may be about $200 \mathrm{~m}$ long based on field observations.

\section{Lithologic unit in hanging wall (HW) and footwall (FW)}

Both HW and FW are in bedded and nonwelded tuff, pumiceous airfall and subordinate reworked tuff originally mapped as the Lower Member of the Indian Trail Formation (Gibbons and others, 1963); reinterpreted as the Tunnel Formation on the digital map of the NTS (Tn of Slate and others, 2000). Station is at the top of a brick red nonwelded tuff with scattered $1 \mathrm{~cm}$ white pumice.

\section{Description of fault core}

No fault core was observed in outcrop. Fault slip plane is exposed (fig. A19) and is locally polished to a glassy surface with slickenlines that rake $80^{\circ} \mathrm{S}$. in the plane of the fault; last episode of fault motion was almost pure dip-slip motion. Fault plane is gently corrugated and has minor drusy quartz mineralization on the fault surface.

\section{Description of damage zone}

Fault-related damage is best expressed in light gray nonwelded tuff in the hanging wall (A, fig. A18). Damage zone is $0.5-0.7-\mathrm{m}$ wide and consists of small $(10-20 \mathrm{~cm})$, anastamosing fractures that are subparallel to the fault and dip toward the fault plane. Outside of this zone, hanging-wall rocks show no discernible fault influence. Damage zone is confined to the region between the main fault and a minor hanging-wall splay fault (fig. A18). 


\section{Field station 06NTS6 - photographs}

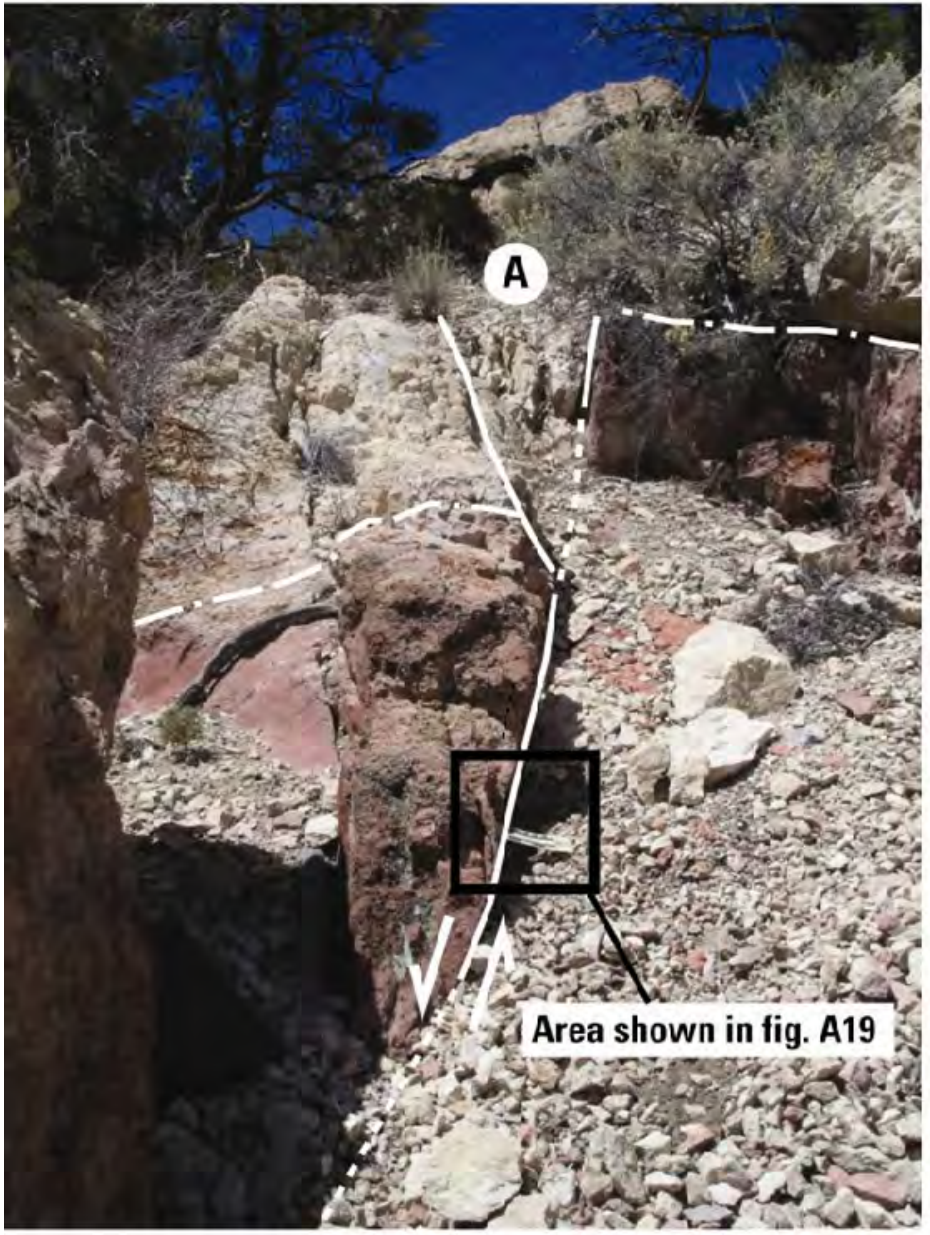

Figure A18. View of small fault in Tunnel Formation. Arrows show relative sense of offset on the fault. Fault is shown as a solid line where exposed in bedrock, short dashed where projected beneath cover. White dash-dot lines indicate top of brick red tuff and document the amount of fault offset.

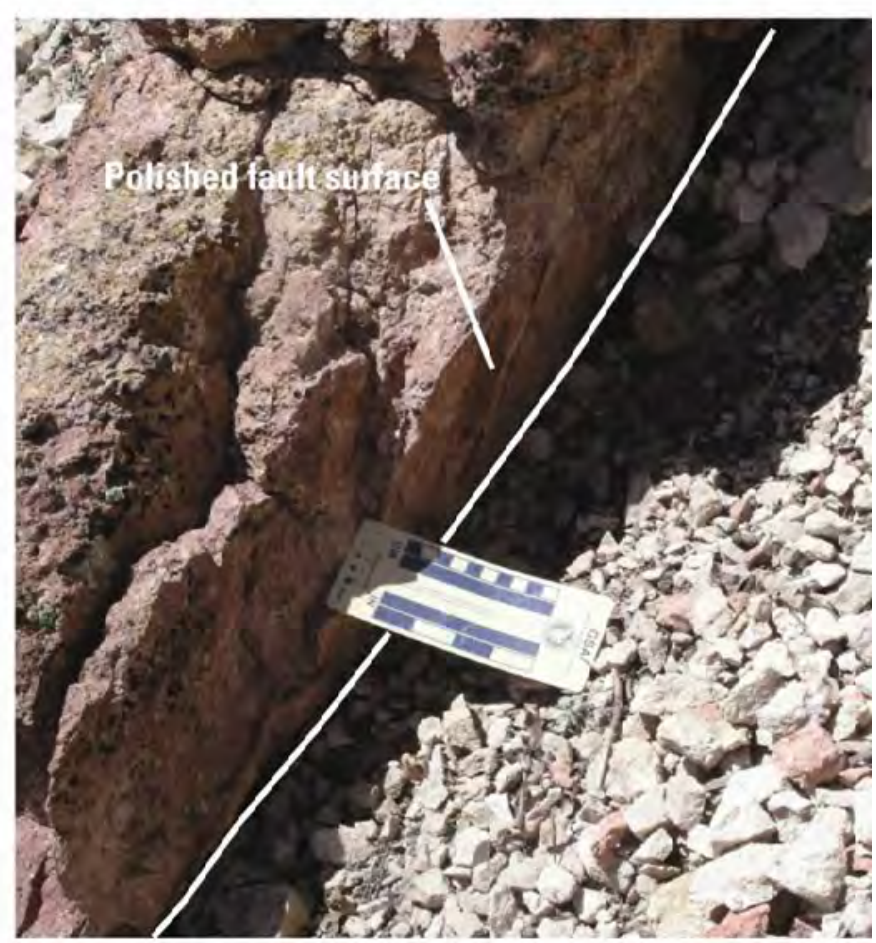

Figure A19. Detail of fault plane showing locally polished surface. Small subdivisions at the upper edge of the scale are 1 centimeter. 


\section{Field station 06NTS7}

\section{Station description}

Station is located on the Rainier Mesa quadrangle (fig. A1). Station is on eastern flank of Rainier Mesa, to the west of the Stockade Wash road. Station is downhill and $10 \mathrm{~m}$ east of 06NTS6.

\section{Fault orientation $135^{\circ} / 85^{\circ} \mathrm{W}$.}

\section{Sense of slip and amount of offset}

Amount of slip is unknown. Slickenlines are well developed on fault plane in dark red marker bed (fig. A20). Slickenlines rake to the southeast about $5^{\circ}$ in the plane of the fault, indicating nearly pure strike-slip motion (fig. A21). From asymmetry of striae on fault zone surface, slip appears to have been left-lateral, unusual for a northwest-striking fault at the NTS.

\section{Length of fault trace in map view}

Fault is not shown on 1:24,000-scale geologic map of the Rainier Mesa quadrangle (Gibbons and others, 1963). Fault trace at least $100 \mathrm{~m}$ long based on field observations, but is covered at both ends.

\section{Lithologic unit in hanging wall (HW) and footwall (FW)}

Both HW and FW are in nonwelded tuff and pumiceous airfall originally mapped as the Lower Member of the Indian Trail Formation (Gibbons and others, 1963); reinterpreted as unit 3BC of the Tunnel Formation on the digital map of the NTS (Tn of Slate and others, 2000). Station is near the top of a brick red nonwelded tuff with scattered 1-cm white pumice.

\section{Description of fault core}

No fault core was observed in outcrop. Fault slip plane is exposed (fig. A21) and slickenlines are highly polished and deeply grooved, some as deep as $2 \mathrm{~mm}$ into fault surface. Drusy quartz mineralization is present on the fault surface at the base of the outcrop.

\section{Description of damage zone}

Fault-related damage is virtually nonexistent. Fault plane can be traced upward into tan, pumiceous, nonwelded tuff that shows virtually no fault effect, even adjacent to the slip plane. 


\section{Field station 06NTS7 - photographs}

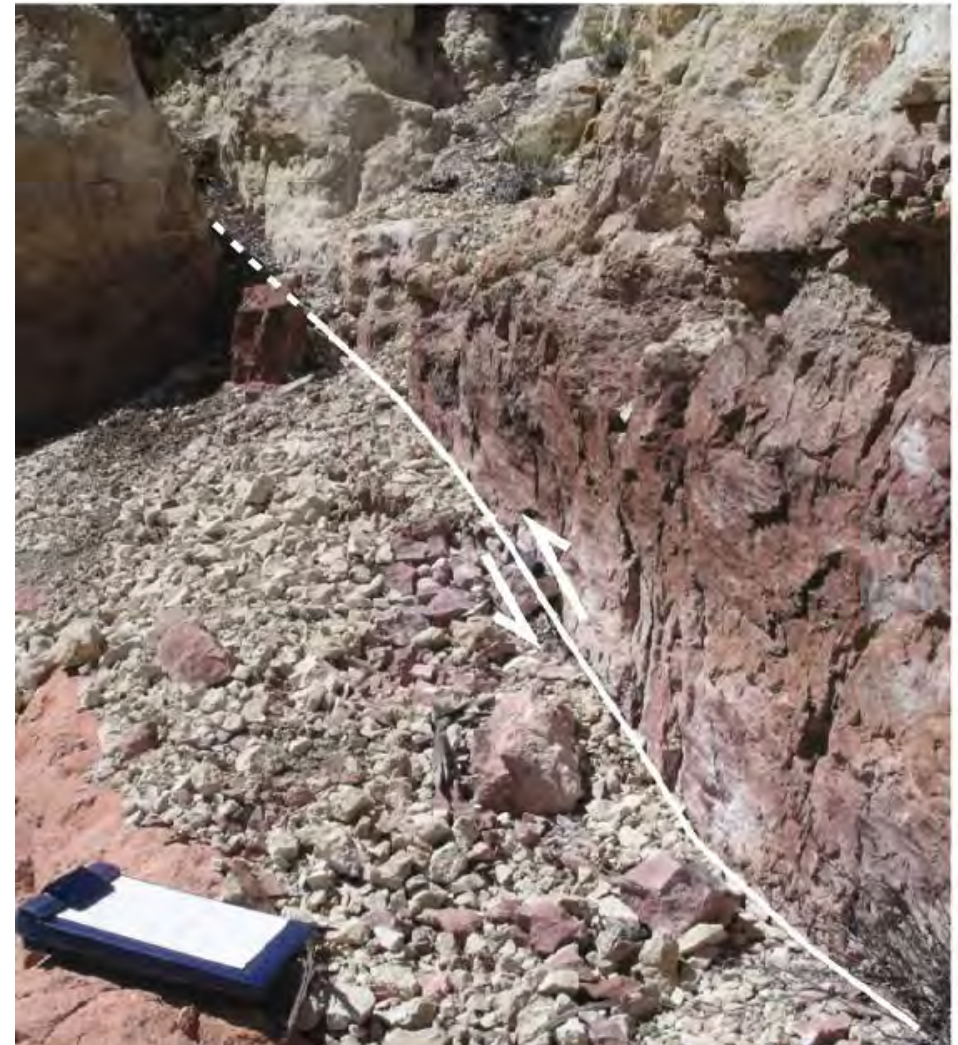

Figure A20. View of small strike-slip fault in Tunnel Formation. Fault is shown as a solid line where exposed in bedrock, dashed where projected beneath cover. Arrows show relative sense of offset on the fault.

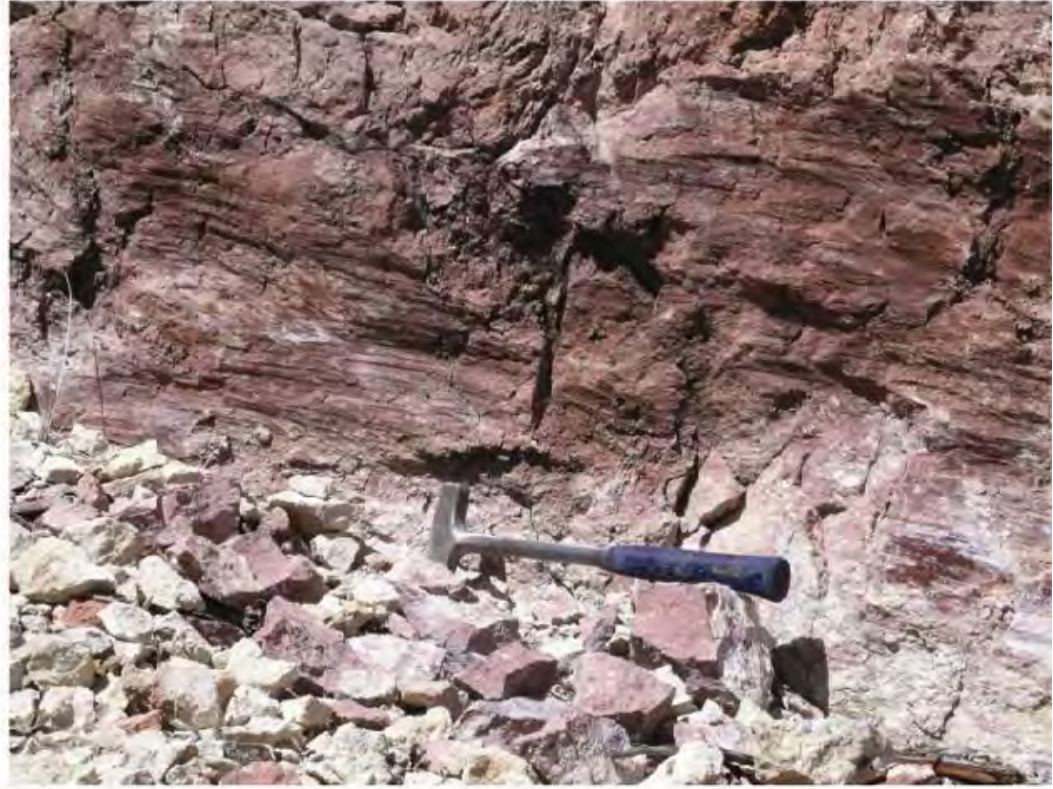

Figure A21. Detail of fault plane. Plane is locally polished to a glassy surface with slickenlines that rake $5^{\circ}$ southeast in the plane of the fault. 


\section{Field station 06NTS8}

\section{Station description}

Station is located on the Rainier Mesa quadrangle (fig. A1). Station is on eastern flank of Rainier Mesa, to the west of the Stockade Wash road. Station is in wash that drains to the north of the U12n tunnel portal. Fault is exposed on the north flank of the wash (fig. A21).

Fault orientation Two slip planes are well-exposed; they are probably splays that merge at depth. Within red, pumiceous, nonwelded tuff is a slip plane oriented $345^{\circ} / 85^{\circ} \mathrm{NE}$ with welldeveloped slickenlines on the fault surface. The main slip plane separates the white bedded tuffs from the red nonwelded tuff (figs. A22 and A23) and has an orientation of $155^{\circ} / 80^{\circ} \mathrm{S}$. Fault plane is gently undulating with well-developed slickenlines.

\section{Sense of slip and amount of offset}

Fault has 20 to $25 \mathrm{~m}$ of normal, southwest-side-down offset based on offset of distinctive marker beds in outcrop (fig. A22).

\section{Length of fault trace in map view}

At least $1 \mathrm{~km}$ based on 1:24,000-scale geologic map (Gibbons and others, 1963). Fault trace is covered at southeast end where it presumably merges with other faults in wash bottom. Northwest end of fault terminates within Tunnel Formation; fault does not offset Rainier Mesa Tuff at the top of the mesa.

\section{Lithologic unit in hanging wall (HW) and footwall (FW)}

Both HW and FW are in nonwelded tuff and pumiceous airfall originally mapped as the Lower Member of the Indian Trail Formation (Gibbons and others, 1963); reinterpreted as unit 3BC of the Tunnel Formation on the digital map of the NTS (Tn of Slate and others, 2000). Station is near the base of a brick red nonwelded tuff with scattered 1-cm white pumice, underlain by bedded, possibly reworked, white pumiceous ash-fall deposits.

\section{Description of fault core}

Fault zone architecture, from hanging wall to footwall, as follows (fig. A23):

A. Hanging-wall tuff with block fracturing spaced $0.5 \mathrm{~m}$;

B. a 5-8-centimeter-wide fault core zone of matrix-supported breccia adjacent to the splay fault, breccia fragments are exclusively from the hanging wall;

C. a 10-30-centimeter-wide zone of clast-supported breccia. Breccia fragments are exclusively from the hanging wall and are $0.5 \mathrm{~m}$ long and about $20 \mathrm{~cm}$ in diameter;

D. a 10-centimeter-wide fault core zone of comminuted footwall tuff that has a pronounced lensoid or sigmoidal fabric at the $1-2 \mathrm{~cm}$ scale;

E. a 1-m-wide zone of fault-related fracturing in the footwall, beyond which is unbroken nonwelded tuff.

\section{Description of damage zone}

In hanging wall, blocky fracturing extends 2 to $3 \mathrm{~m}$ away from fault, with fracture spacing about $0.5 \mathrm{~m}$. Hanging-wall rocks may be affected by subsidiary fault splays. Footwall fracturing progressively decreases in intensity in the $1 \mathrm{~m}$ adjacent to the fault zone. Within this damage zone, fractures are predominantly subparallel to the fault and block size increases from 3 to $4 \mathrm{~cm}$ 
near the fault to about $10 \mathrm{~cm}$ at the limits of the footwall damage zone. No fault-related damage farther than $1 \mathrm{~m}$ from fault in either direction. 


\section{Field station 06NTS8 - photographs}

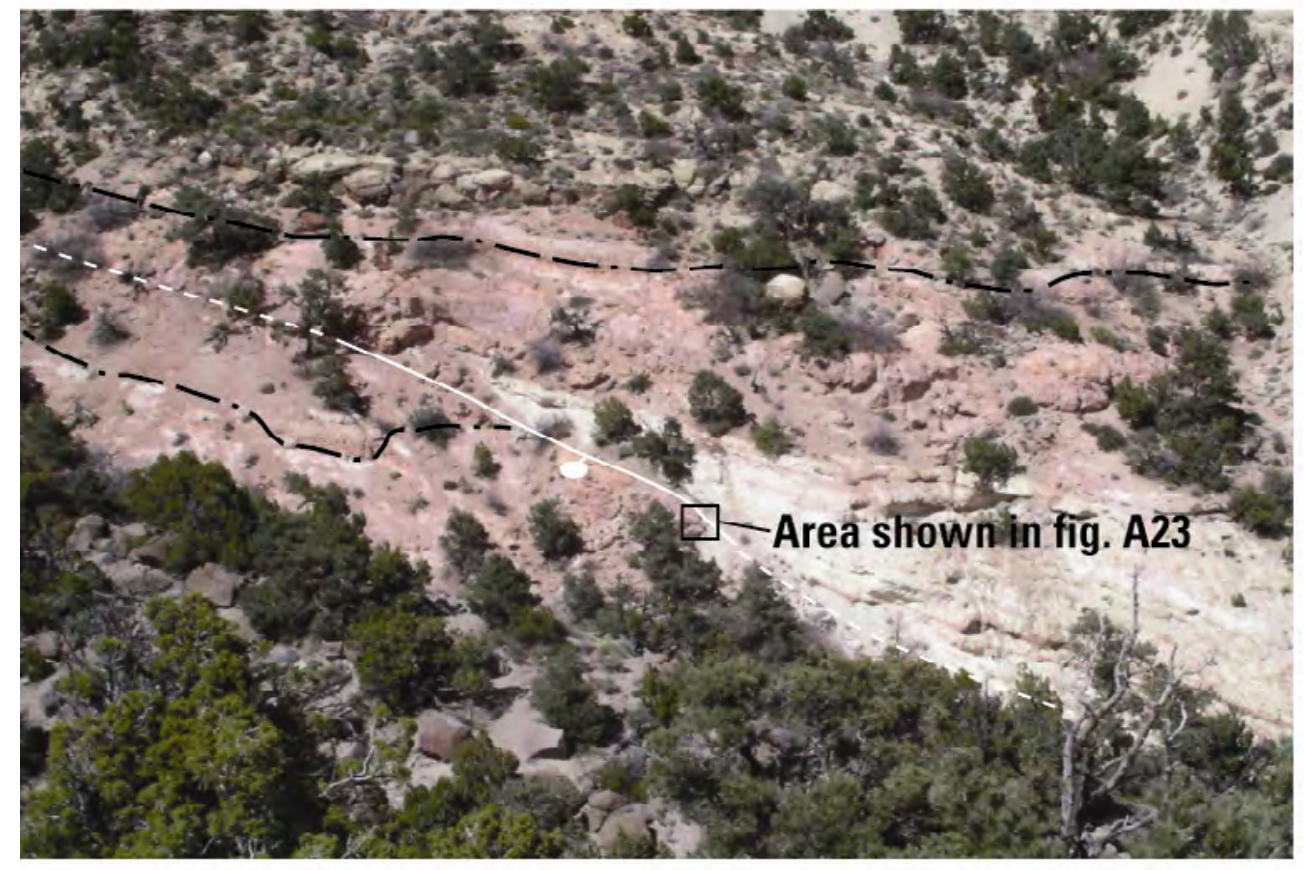

Figure A22. View from ridgeline looking down and to the north on station 06NTS08. Fault is shown as a solid line where exposed in bedrock, dashed where projected beneath cover. Ball and bar is on downthrown side of fault and shows relative sense of displacement. Dot-dash lines indicate the base of a distinctive marker bed used to measure offset on the faults. Field of view is approximately 100 meters.

Figure A23. Detail of fault zone, looking northwest, parallel to the strike of the fault. Arrows show relative sense of movement across the fault zone. Fault-related damage zones, labeled $A$, $B, C, D$, and $E$, are described in the text.

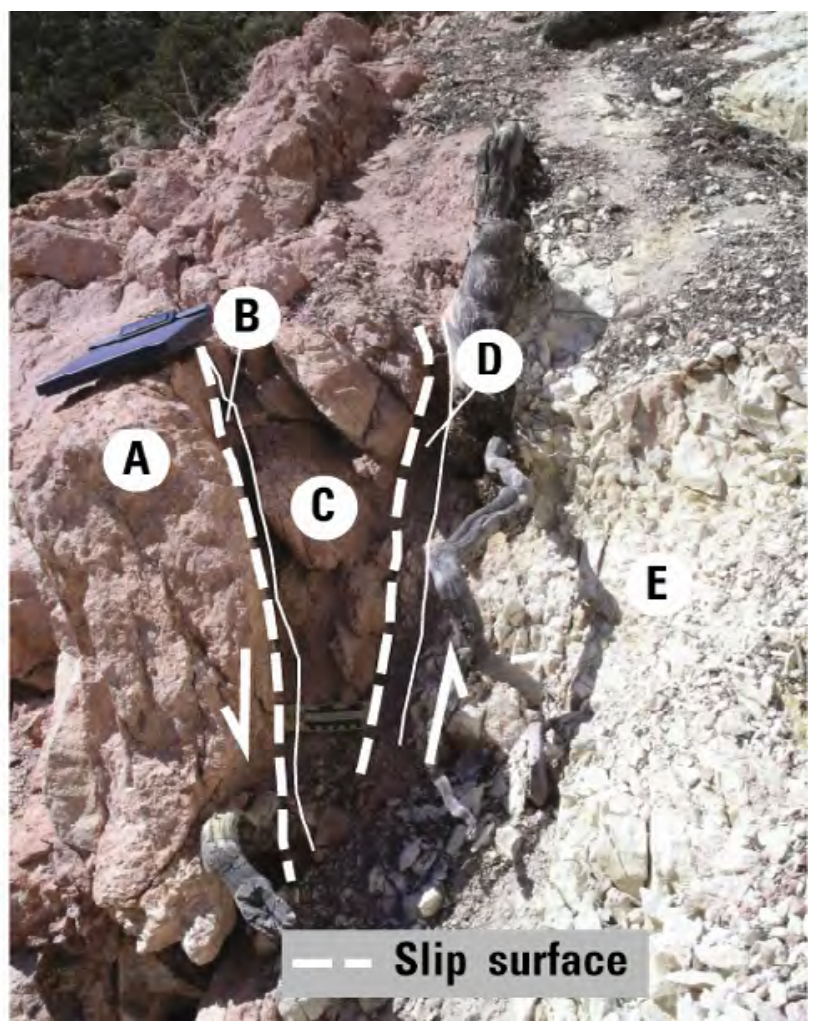




\section{Field station 06NTS9}

\section{Station description}

Station is located on the Rainier Mesa quadrangle (fig. A1). Station is on southern flank of Rainier Mesa, to the north of the Stockade Wash road. Station is in low cliffs of partly welded Bullfrog Tuff that flank the roadway.

Fault orientation There are a series of small offset strike-slip faults (fig. A24) that strike 125$130^{\circ}$ and dip steeply at about $85^{\circ} \mathrm{W}$.

\section{Sense of slip and amount of offset}

Aggregate dip slip across these faults is about $1 \mathrm{~m}$, southwest-side-down. Amount of strike slip is unknown. Slickenlines are well developed on fault planes (fig. A25). Slickenlines rake to the southeast about $5^{\circ}$ in the plane of the fault, indicating sinistral strike-slip motion (fig. A24).

\section{Length of fault trace in map view}

Zones of faults is exposed where it cuts the top of the cliff band; faults are traceable for about 40 $m$ in length. Fault is not shown on 1:24,000-scale geologic map of the Rainier Mesa quadrangle (Gibbons and others, 1963).

\section{Lithologic unit in hanging wall (HW) and footwall (FW)}

Both HW and FW are in poorly welded tuff originally mapped as the Stockade Wash Member of the Piapi Canyon Formation (Gibbons and others, 1963); reinterpreted as Bullfrog Tuff on the digital map of the NTS (Slate and others, 2000). Rock is zeolitically altered; white fibrous zeolites are common in the groundmass of the tuff.

\section{Description of fault core}

Core zones are very thin - typically consisting of up to $1 \mathrm{~cm}$ of highly comminuted wall rock with a subtle sigmoidal fabric. Most of the fault surfaces are open with apertures of about $0.5 \mathrm{~cm}$ and are free of core material. Comminuted material appears most commonly at fault bends.

\section{Description of damage zone}

Width of individual damage zones is obscured by the large number of slip planes that transect the outcrop. Each slip plane appears to have a zone of fracturing about $30 \mathrm{~cm}$ wide surrounding it on either side of the fault. The total width of fault-related damage is about $4 \mathrm{~m}$ wide. 


\section{Field station 06NTS9 - photographs}

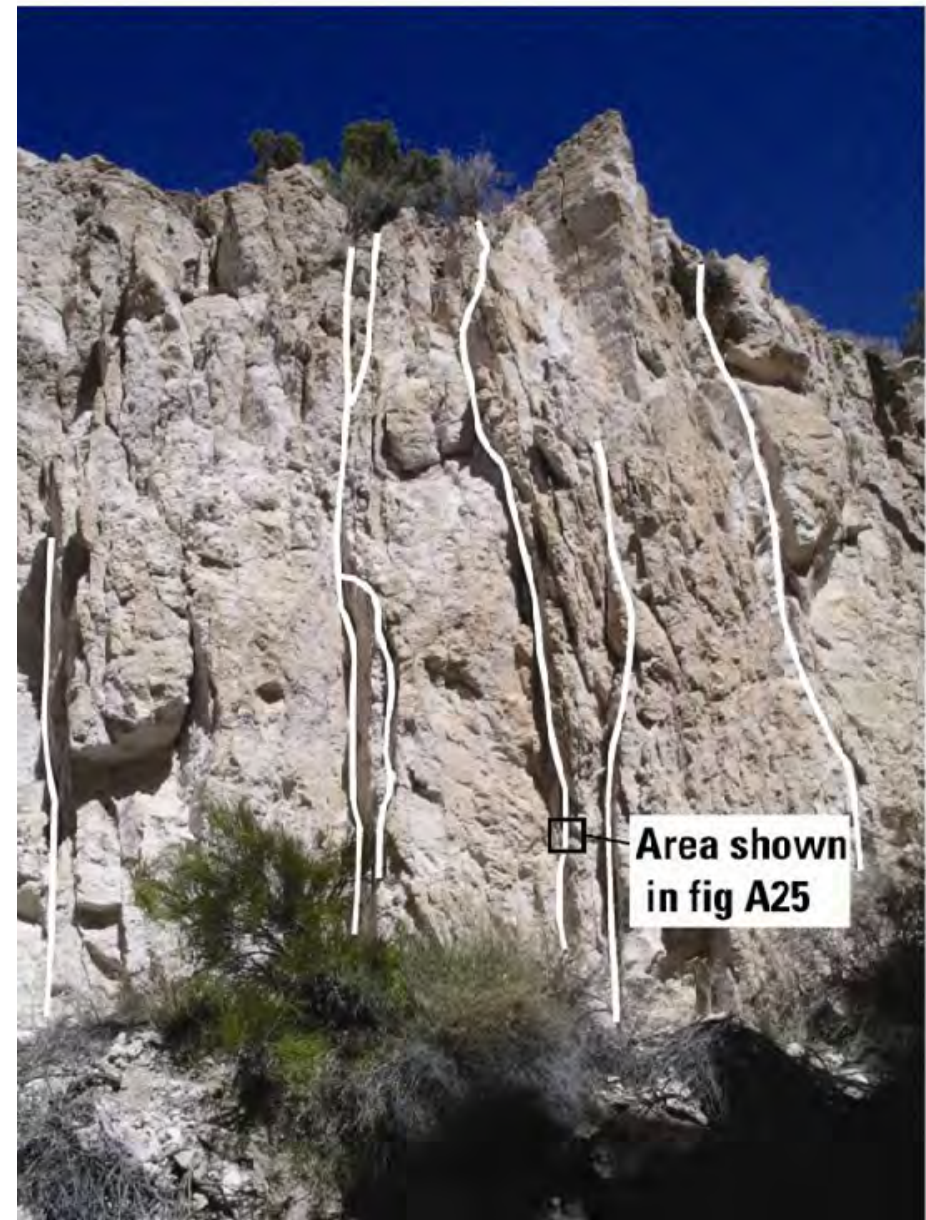

Figure A24. Numerous small strike-slip faults in poorly welded Bullfrog Tuff south of Rainier Mesa. White lines indicate slip planes.

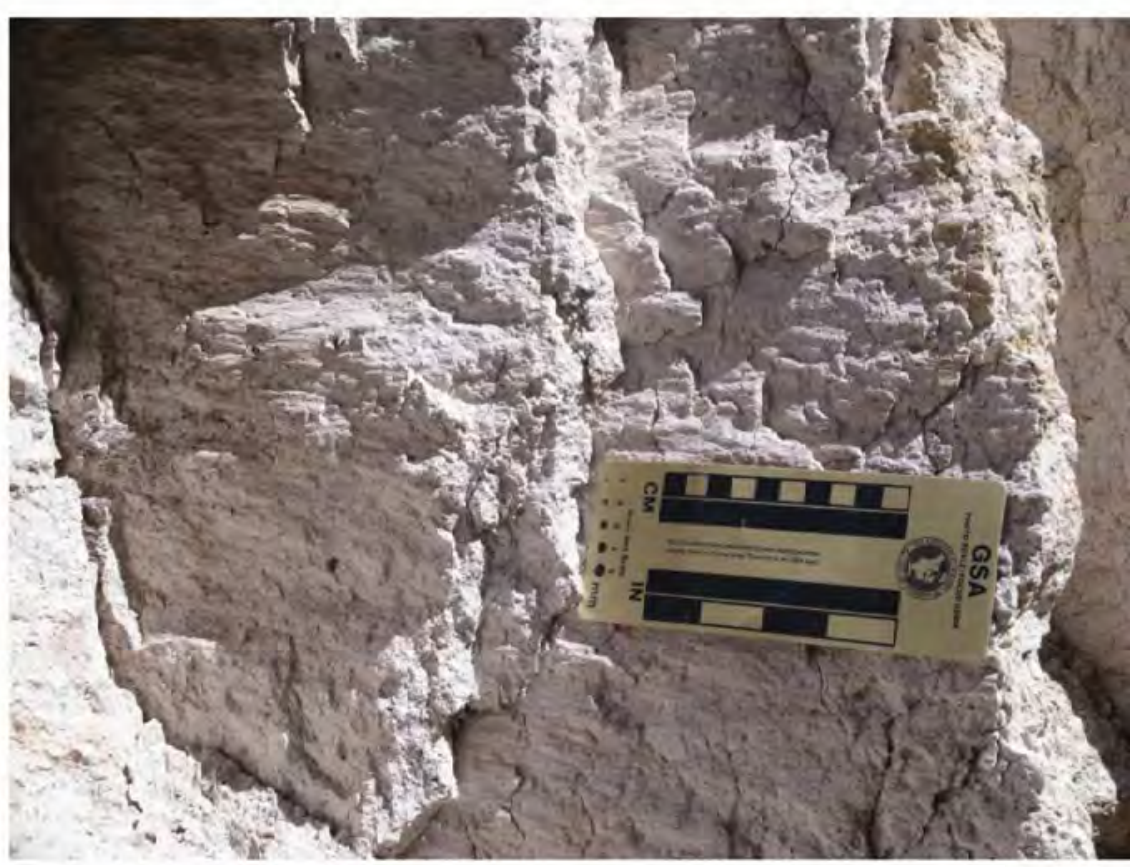

Figure A25. Detail of slip planes showing well-developed slickenlines. Upper bar of scale bar is in centimeters. 


\section{Drill hole UE-12n 6}

\section{Station description}

Drill hole is on Rainier Mesa and has a drilled depth of 706 m. Fault is at 415-m depth.

Fault orientation Drill core not oriented. Strike is probably northwest, based on orientation of structures present in tunnels beneath Rainier Mesa, dip is $60^{\circ}$.

\section{Sense of slip and amount of offset}

The fault has normal, southwest-side down displacement with stratigraphic offset of about 2 to 3 $\mathrm{m}$, based on correlation with mapped fault in Area 12 tunnels.

\section{Length of fault trace in map view}

Fault is not shown on 1:24,000-scale geologic map (Gibbons and others, 1963). Fault trace may be about $200 \mathrm{~m}$ long based on field observations.

\section{Lithologic unit in hanging wall (HW) and footwall (FW)}

Both HW and FW are in nonwelded tuff of unit 5 of the Tunnel Formation (Tn of Slate and others, 2000).

\section{Description of fault core}

Fault core consists of a fault slip plane with slickenlines and brownish-yellow staining. Core zone width about $1 \mathrm{~mm}$.

\section{Description of damage zone}

Above and below slip plane, rock is broken and there are other polished surfaces. Rock is broken for about $0.3 \mathrm{~m}$ in the hanging wall and about $1 \mathrm{~m}$ in the footwall. Most breaks are perpendicular to the core axis. 


\section{Drill hole UE-7az}

\section{Station description}

Drill hole is in Yucca Flat, NTS use area 7 and has a drilled depth of $744 \mathrm{~m}$. Fault is at 559-m depth.

Fault orientation Drill core not oriented; strike is unknown. There are several slip planes in this zone. The uppermost slip plane dips at $50^{\circ}$; lower slip plane dips at $35^{\circ}$.

\section{Sense of slip and amount of offset}

Normal sense of slip; hanging-wall rocks reported as unit 3BC of the Tunnel Formation (Tn of Slate and others, 2000); footwall rocks are logged as stratigraphically lower unit 3A of the Tunnel Formation. Stratigraphic offset is unknown.

\section{Length of fault trace in map view} Unknown.

\section{Lithologic unit in hanging wall (HW) and footwall (FW)}

Hanging-wall rocks reported as unit 3BC of the Tunnel Formation (Tn of Slate and others, 2000); footwall rocks are logged as stratigraphically lower unit 3A of the Tunnel Formation. Both units are reworked tuff and air-fall tuff; rocks are zeolitized and well indurated.

\section{Description of fault core}

Fault core consists of nine identifiable slip surfaces, four of which are healed with silica cement.

\section{Description of damage zone}

Damage zone is approximately $3 \mathrm{~m}$ wide, consisting of both clast- and matrix-supported breccia. Clasts in breccia are angular, unsorted and range up to $5 \mathrm{~cm}$ in size. Clasts are dark brown to maroon tuff and lithic clasts. Sharp contact of breccia with fractured rock of surrounding damage zone. Surrounding the breccia is interval of relatively widely spaced slip surfaces that is about 8 $\mathrm{m}$ wide in footwall and $7 \mathrm{~m}$ wide in hanging wall. Slip surfaces are spaced an average of about 1 $\mathrm{m}$ apart, and subparallel to the main fault, and many are healed with 1 to $4 \mathrm{~mm}$ of opaline silica. 


\section{Drill hole UE-7az}

\section{Station description}

Drill hole is in Yucca Flat, NTS use area 7, and has a drilled depth of $744 \mathrm{~m}$. Fault is at 660-m depth.

Fault orientation Drill core not oriented; strike is unknown, slip plane dips at $70^{\circ}$.

\section{Sense of slip and amount of offset}

Amount of slip is unknown; sense of slip is normal based on the presence of faint slickenlines with a rake of $90^{\circ}$ in the plane of the fault.

\section{Length of fault trace in map view}

Unknown.

\section{Lithologic unit in hanging wall (HW) and footwall (FW)}

Both HW and FW rocks are logged as Crater Flat Group tuff. Tuff is nonwelded to partly welded, moderately indurated and friable. Tuff has abundant pumice and quartz with lesser biotite.

\section{Description of fault core}

Fault core is approximately $4 \mathrm{~mm}$ wide. Core consists of dark brown clay gouge with no visible structure or cementation. Sharp contact with surround damage zone.

\section{Description of damage zone}

Damage zone consist of a $0.3-\mathrm{m}$-wide rubbly interval of clast-supported breccia in the footwall. Clasts are subrounded and 2 to $4 \mathrm{~cm}$ in size. Outside of this interval, fractures quickly return to background intensity of apparent spacing of 1 fracture per meter. 


\section{Drill hole USGS Test Well B}

\section{Station description}

Drill hole is in Yucca Flat, NTS use area 6, and has a drilled depth of $511 \mathrm{~m}$. Fault at 358-m depth.

Fault orientation Drill core not oriented. Strike is unknown, dip is about $55^{\circ}$.

Sense of slip and amount of offset

Unknown.

Length of fault trace in map view

Unknown.

\section{Lithologic unit in hanging wall (HW) and footwall (FW)}

Both HW and FW are in Rainier Mesa Tuff (Tmr of Slate and others, 2000). Partly welded, vitric, pumiceous, crystal-rich tuff; footwall rocks are slightly less welded.

\section{Description of fault core}

Fault has the appearance of a large open fracture partially filled with breccia. Contacts with damage zone appear gradational.

\section{Description of damage zone}

Fault damage zone consists of about $2 \mathrm{~m}$ of poorly cemented matrix-supported breccia. Clasts are angular and unsorted, ranging up to $3 \mathrm{~cm}$ in size. Some clasts have polished surfaces with manganese oxide staining. Surrounding the breccia is a fractured zone at least $3 \mathrm{~m}$ wide; observation is limited to the length of the core run. Damage zone consists of fractures spaced at $10 \mathrm{~cm}$. 